\title{
REGULATION OF INSTITUTIONAL INVESTMENT IN ALBERTA
}

\section{BERNARD W. CROTTY*}

This article is an analysis of how various types of institutions in Alberta are currently regulated in respect of their investment activities both at common law and pursuant to specific statutory measures. It is suggested that the current largely legal list approach to regulation is not effective and does not allow for the application of modern financial techniques, such as portfolio theory. Crotry concludes by discussing how' other jurisdictions have approached this issue and advocates the general adoption of prudent investment standards in Alberta and a larger evaluation of the role of Alberta institutions.
Le présent article analyse la façon dom les activités $d$ 'investissement de diverses institutions albertaines sont présentement régies tant au niveau de la common law qu'en termes de mesures statutaires particulières. L'auteur suggère que lapproche des placements admissibles n'est pas efficace et qu' elle ne permet pas lapplication des techniques financières modernes comme celle de la théorie du portefeuille. Crotty conclut en examinant comment d'autres juridictions ont abordé le problème; il recommande l'adoption générale de principes de gestion prudente en Alberta et une évaluation plus vaste du rôle des institutions de la province.

\section{TABLE OF CONTENTS}

I. INTRODUCTION . . . . . . . . . . . . . . . 1142

II. REGULATION IN ALBERTA - GENERALLY . . . . . . . . . 1143

III. REGULATION IN ALBERTA - INVESTMENT

ACTIVITY . . . . . . . . . . . . . . . . . . . 1144

A. PRIVATE SECTOR PENSION FUNDS $\ldots \ldots \ldots \ldots \ldots 1144$

B. PUBLIC SECTOR PENSION FUNDS $\ldots \ldots \ldots \ldots \ldots \ldots 1146$

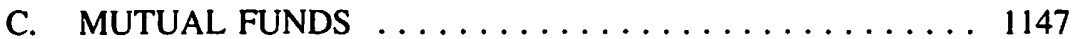

D. INSURANCE COMPANIES $\ldots \ldots \ldots \ldots \ldots \ldots \ldots 1149$

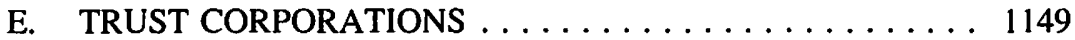

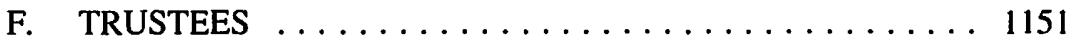

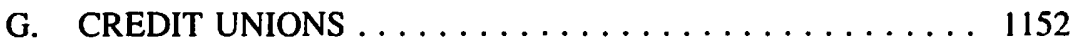

H. ALBERTA HERITAGE SAVINGS

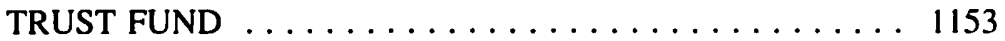

IV. REGULATION IN ALBERTA

- AN EVALUATION ..................... 1154

A. THE QUALITATIVE LEGAL LIST $\ldots \ldots \ldots \ldots \ldots \ldots 1155$

B. MODERN FINANCE THEORY $\ldots \ldots \ldots \ldots \ldots \ldots \ldots 1156$

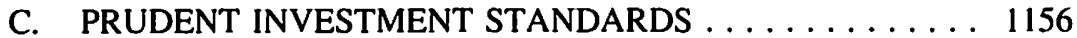

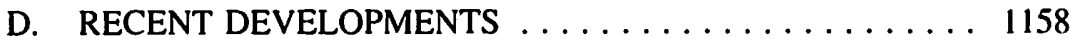

E. ADOPTION OF PRUDENT INVESTMENT STANDARDS $\ldots \ldots \ldots \ldots \ldots \ldots \ldots 1162$

F. THE ROLE OF INSTITUTIONS $\ldots \ldots \ldots \ldots \ldots \ldots \ldots 1162$

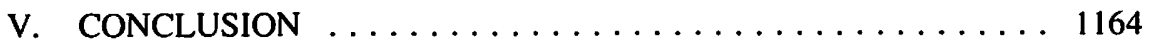

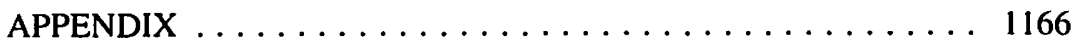

McCarthy Tétrault, London, England Office. Member of the Alberta and Ontario Bars. Member of the Law Society of England. 


\section{INTRODUCTION}

In recent years, the financial press in Canada and elsewhere has contained many reports of individuals deserting the financial markets and of the increasingly significant role that large institutions have come to play in such markets.' While this increasing role of institutions at the expense of individual investors has been bemoaned by some, the likelihood is that for good financial reasons, including diversification and professional management, individual investors will continue and increasingly prefer to channel their investment activity through institutions. It is, therefore, unlikely that the dominance of institutional investors will be reversed in coming years.

The expanding role of institutions in the financial market place raises many important legal and larger public policy questions given the potential influence that institutions can exert. This potential for influence has not been ignored with observers suggesting roles for institutions such as protector of the small investor, enforcer of the company's social responsibilities, provider of funds, stock market stabilizer or performance monitor. ${ }^{2}$ Against this backdrop of increasing institutional dominance and calls for new roles for institutions, it seems particularly appropriate to consider how we regulate institutional investment in Alberta and whether this regulatory regime is effective in the current context.

This paper will begin by discussing both the general and specific legal standards which are applicable to the investment activities of provincially regulated institutions. This will be followed by an examination of such legal framework generally and in terms of modern finance theory and recent legislative and judicial developments. A move to a generalized prudent investment standard will then be considered, followed by a review of the roles Alberta institutions are currently required to undertake. In order to provide focus, only institutions subject to direct provincial regulation will be considered. Although federally regulated banks, pension funds, investment companies, loan companies, insurance companies and trust companies may and do carry on business in Alberta, they will not be considered in view of the absence of direct provincial regulation. Certain aspects of federal income tax regulation which impact upon the tax exempt status of pension funds, have a significant ability to indirectly regulate the investments of Alberta pension funds, and will be considered in this light.

I. See: The Financial Post, (4 January 1991) 40, where it was reported that the Investment Dealers Association of Canada disclosed that $72.3 \%$ of broker arranged trades on the Toronto Stock Exchange in the first months of 1990 were made for institutions. This was reported as up slightly from the institutional dominance of $71.3 \%$ for the first nine months of 1989 and up significantly from $65.3 \%$ during the first nine months of 1988 . Before worldwide markets were devastated by the crash of October 1987, it was reported that activity on the Toronto Stock Exchange was split almost evenly between individuals and institutions.

2. J. Farrar \& M. Russell, "The Impact of Institutional Investment on Company Law" 10:5 The Company Lawyer 108. 


\section{REGULATION IN ALBERTA - GENERALLY}

The detailed rules governing investments by Alberta institutions are considered below. However, prior to looking at these detailed rules, it is important to recognize and briefly discuss some aspects of the common law and other laws of general application which impose duties and restrictions on the investment activities of Alberta institutions.

Trustees holding pension fund assets, investment fund managers and directors of insurance companies, trust corporations and credit unions are all subject to varying forms of fiduciary duties. ${ }^{3}$ Relationships are further clouded by the existence of various contractual duties and arrangements. Investment managers have management contracts with trustees or other entities and mutual funds have various contractual obligations to investors and are also subject to the disclosure and other requirements of the Securities Act $^{4}{ }^{4}$ The managements of insurance companies, trust corporations and credit unions are also subject to the general regulatory rules in the Insurance Act, ${ }^{5}$ the Loan and Trust Corporations Act, ${ }^{6}$ and the Credit Union Act respectively.

The obligations placed upon a trustee under the common law, as codified to a large extent in the Trustee Act, ${ }^{8}$ are by far the most relevant in this context given the role of trustees in relation to pension funds, mutual funds and trust corporations. These obligations prohibit trustees from entering into arrangements which place them in a conflict of interest, and impose a positive duty to preserve and protect the assets of the trust and invest such assets in a productive manner. A trustee must also exercise the care and skill that an ordinary prudent person would demonstrate. ${ }^{9}$ With the exception of pension fund trusts, it is important to recognize that these principles of trust law are not mandatory and may be excluded or modified in the governing trust instrument. ${ }^{10}$ This technique is usually employed to one extent or another in commercial trusts of all forms. It cannot be extended to pension fund trusts, in view of provisions in the Regulations to the Employment Pension Plans Act, " which prohibit pension fund trusts from contracting out of the investment provisions specified therein.

The duty to avoid conflicts of interest presents an ongoing problem for trustees and is particularly relevant in the context of modern trust corporations. For example, a trust

3. In the leading Canadian decision of Canadian Aero Services Limited v. O'Malley (1973), 40 D.L.R. 3rd 371, the Supreme Court of Canada established the general principle that an individual in a special confidential relationship with another person is bound by fiduciary duties of good faith, honesty and loyalty. Also see: Loan and Trust Corporations Act, S.A. 1991, c. L-26.5, s. 132 and Credit Union Act, S.A. 1989, c. C-31, s. 73, which largely codify the common law duties of directors. S.A. 1981, c. S-6.1, as amended. See: Parts 5,6 and 8-16 in particular.

R.S.A. 1980, c. I-5, as amended, Part 3.

Supra, note 3, Part 6.

Supra, note 3, Part 6.

R.S.A. 1980, c. T-10, as amended.

D. Waters, The Law' of Trusts in Canada (Toronto: Carswell, 1974) pages 668-690 presents a general discussion of the duties of trustees in this area.

lbid.

Section 36, Employment Pension Plans Regulation, Alberta Regulation 364/86. 
corporation, in the course of its commercial lending activities, might obtain material inside information about a commercial customer. At common law, the trust corporation owes a duty to such a commercial customer not to disclose this confidential information. However, the trust corporation owes a fiduciary obligation to its trust customers and may be in breach of this obligation if it does not use information which it possesses for their benefit. $^{12}$ Clearly, a trust corporation will have to recognize the possibility for such conflicts and attempt to insulate itself from liability. The use of a "Chinese Wall," which blocks the movement of information internally, has been advocated as one solution, but in the absence of statutory recognition, its effectiveness in the Canadian context is less than certain..$^{13}$

The above rules provide the backdrop to specific rules regulating the investment activity of Alberta institutions. They provide the basic operating environment and impose significant constraints and obligations on institutions above and beyond the specific rules governing institutional investment which are considered below.

\section{REGULATION IN ALBERTA - INVESTMENT ACTIVITY}

Institutional investment in Alberta is also regulated by specific statutes speaking to distinct forms of institutions. Each of these statutes specifically regulates the types of investments which the institution in question is permitted to make, in addition to providing a general regulatory framework. The Appendix compares the scope of permitted investments among institutions in summary fashion. This Appendix is general in nature and has been included for comparative purposes. In view of the extremely technical nature of the underlying statutory provisions, reference should be made to the specific provisions in question, in the event that detailed interpretation is required. The discussion below commences with consideration of the investment regime governing private sector pension funds. The review of the provisions applicable to other institutions, is generally effected by way of comparison to the private sector pension fund provisions.

\section{A. PRIVATE SECTOR PENSION FUNDS}

As of March 31, 1991 1,452 private sector pension plans representing 390,988 members and $\$ 6.8$ billion in assets were registered in the Province of Alberta. ${ }^{14}$ Investments by private sector pension funds in the Province of Alberta are generally governed by the Employment Pensions Plan Act. ${ }^{15}$ The investment provisions established by this Act cannot be varied or amended by the parties by contract. ${ }^{16}$ This clearly distinguishes

Sce: W. Goodman, M. Herman \& J. Blidner, "Conflicts of Interest, Trust Companies and the Chinese Wall" (1984) 9 Canadian Business Law Journal 435.

lbid. at 436-437, 454-457 and 463. In this context it should be noted that both the English High Court and Court of Appeal in recent decisions in David Lee \& Co. (Lincoln) v. Coward Chance, [1991] Ch. 259 and Re: A Firm of Solicitors, The Times (20 June 1991) refused to accept that Chinese Walls are effective. It should also be noted that the Loan and Trust Corporations Act, supra, note 3, does not specifically recognize Chinese Walls.

1s. Government of Alberta, Alberta Labour Employment Pensions Branch, Statistics Report 1990-91.

15. S.A. 1986, c. E-10.05, as amended.

16. Supra, note 11 . 
private sector pension funds from other investment schemes where a trustee is involved, such as a mutual fund. The parties cannot vary the underlying trust instrument to permit latitude of investment, with the result that investments must be effected in accordance with the statutory standards.

The Employment Pension Plans Act adopts ${ }^{17}$ the permitted investments prescribed on January 1, 1987 by the Regulations to the Pension Benefits Standards Act, 1985 (Canada). ${ }^{18}$ The qualitative legal list established specifies tests and standards which in the main are designed to ensure preservation and safety of capital. Examples of permitted fixed income investments include: those issued, guaranteed or supported by the federal government, a provincial government, municipal corporations or international lending agencies; federal insurance company issues; fully secured corporate issues; corporate issues meeting specified earnings coverage tests; and trust company guaranteed investment certificates. Examples of permitted equity investments include five year seasoned preferred shares and common shares which have paid dividends of or otherwise had earnings available of $4 \%$ in four of the last five years. Other authorized investments include $75 \%$ loan-to-value mortgages, insured mortgages, and income producing real estate and Canadian resource properties subject to high quality leases or earnings tests.

Private sector pension funds are provided a measure of flexibility through a $7 \%$ of book value general real estate or Canadian resource property basket clause and a $7 \%$ of book value basket clause for investments other than real estate or Canadian resource property. Investments in real estate corporations and Canadian resource property corporations are also permitted. Mutual fund investments are permitted, if the underlying investments would qualify, subject to the requirement that a real estate investment trust may not have more than $10 \%$ of the book value of its net assets in any one property and may not otherwise exceed $10 \%$ of the book value of the pension fund assets. Options or futures may also generally be traded as part of a defensive strategy.

Diversification of the portfolio is addressed through provisions which limit direct holdings of any one real estate or Canadian resource property to $4 \%$ of the portfolio, and a $10 \%$ portfolio ceiling for real estate and Canadian resource corporations. In addition, not more than $15 \%$ of the portfolio may be held directly or indirectly in Canadian resource properties. Finally, a private sector pension fund may not hold more than $10 \%$ of its portfolio in the securities of any one issuer.

As will be discussed further below, a very important provision for the purposes of corporate governance is a restriction which limits private sector pension funds to holding not more than $30 \%$ of the shares of any particular issuer. This provision clearly limits the opportunities for Alberta private sector pension funds to participate in the market for corporate control, and along with the above $10 \%$ in one issue-restriction, are the only direct restrictions limiting investment by a pension fund in an employer/plan sponsor. 
An exception to the above regime is provided by the Teachers Retirement Fund, which is independently constituted and governed by the Teachers Retirement Fund Act. ${ }^{19}$ A qualitative legal list is employed which is broadly similar, but slightly less expansive, than the list of permitted investments surveyed above which applies to private sector pension funds.

While it is not the purpose of this paper to discuss federal regulation, the impact that federal income tax law has on all levels of pension fund investment is too important to be ignored. In simplest terms, a private or public sector pension fund will be exempt from tax under Part I of the Income Tax Act (Canada) ${ }^{20}$ if it is registered with the Minister of National Revenue, subject to certain exceptions. The need to register the pension fund clearly has a significant impact on the nature of pension fund investment and, in a practical sense, amounts to indirect federal regulation of pension fund investment in Alberta.

The question of registration by the Minister of National Revenue is discretionary, although guidelines have been released by Revenue Canada. ${ }^{21}$ The exceptions to the tax environment generally operate such that a pension fund will be liable to tax in specified instances. ${ }^{22}$ One of the most significant exceptions is found in Part XI of the Income Tax Act, which requires a pension fund to pay a tax at the rate of $1 \%$ per month on the excess of its foreign property holdings above the permitted level. ${ }^{23}$

It is beyond the scope of this paper to consider all of the instances where an Alberta pension fund could be subject to income tax. The important factor to be recognized is that the need to stay within the federal taxation statute results in a significant additional layer of regulation of pension funds in Alberta.

\section{B. PUBLIC SECTOR PENSION FUNDS}

Pensions are established for a range of public sector and quasi-public sector employees pursuant to the Local Authorities Pension Plan Act, ${ }^{24}$ Members of the Legislative Assembly Pension Plan Act, ${ }^{25}$ the Public Service Management Pension Plan Act ${ }^{26}$ the Public Service Pension Plan Act, ${ }^{27}$ the Special Forces Pension Plan Act ${ }^{28}$ and the

R.S.A. 1980, c. T-2, as amended.

R.S.C. 1952 , c. 148 , as amended by S.C. $1970-71-72$, c. 63 , and as subsequently amended.

See: Information Circular 72-13R2 dated December 31, 1981.

See: S.S. Heller, "Investments by Canadian Pension Plans," Report of Proceedings of the Thirty-Seventh Tax Conference, 1985 Conference Report (Toronto: Canadian Tax Foundation, 1985) at 42:21 - 42:63.

Subsection 206 (2) provides that the tax is imposed at the end of the month, where the fair market value of foreign property at the date of acquisition is in excess of $16 \%$ (rising to $20 \%$ in 1994) of the aggregate fair market value of all of the property of the pension plan.

S.A. 1985 , c. L-28.1, as amended.

S.A. 1985 , c. M-12.5, as amended.

S.A. 1984 , c. P-34.1, as amended.

S.A. 1984 , c. P-35.1, as amended.

S.A. 1985 , c. S-21.1, as amended. 
Universities Academic Pension Plan Act. ${ }^{29}$ Pursuant to the Pension Fund Act, ${ }^{30}$ the monies associated with these pension funds are administered by the provincial treasurer and may be invested in the manner permitted by Part 5 of the Financial Administration Act. ${ }^{31}$ Part 5 of the Financial Administration Act sets out a prescribed list of investments which the monies associated with the above pension funds may be invested in, which list includes the permitted investments set out on May 31, 1992 in section 86 of the Canadian and British Insurance Companies Act. ${ }^{32}$

The provisions of the Canadian and British Insurance Companies Act, while slightly narrower, largely mirror the permitted investments for private sector pension funds discussed above. The Financial Administration Act provisions add to this list by also allowing investments to be made in securities of the Export Development Corporation, a federal loan company, or those which are guaranteed by a bank, and also permits the use of options, swaps and futures. The only diversification requirement imposed on public sector pensions is that they may not hold more than $30 \%$ of the shares of any one corporation.

An important characteristic of public sector pension funds is that they are effectively guaranteed by the Province of Alberta through its obligation to make payments from the General Revenue Fund and then, to the extent possible, to recoup such monies from the individual pension funds. ${ }^{33}$ Beneficiaries thus should have less of a concern in respect of the solvency of the fund than their private sector counterparts, who have to look generally to their former employers for any deficiency. This does not change the need to carefully consider how public sector pension fund investments are regulated, in that the solvency risk rests ultimately with provincial taxpayers.

\section{MUTUAL FUNDS}

The size and role of mutual funds, and the influence of the various fund managers, have clearly developed to the stage where mutual funds are a very important aspect of the institutional landscape. The term mutual fund in this context is intended to be elastic, speaking to open or closed end unit trust or corporate collective investment vehicles.

Under the Securities Act, ${ }^{34}$ a unit of a mutual fund, or a share if it is a closed end fund, is included in the definition of a security. ${ }^{35}$ Accordingly, units or shares of a fund can only be sold through registrants ${ }^{36}$ after a receipt for the prospectus ${ }^{37}$ of the fund has been issued. Also, and as importantly, investors will have recourse to, and the fund

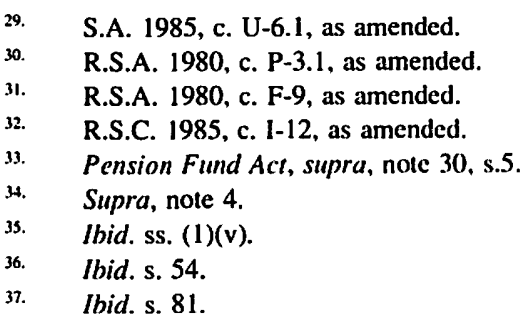


will be subject to, the quasi-criminal and civil remedies set out in the Securities $A c t^{38}$ in respect of misrepresentations or any other failure to meet the regulatory standards set out therein.

Once a mutual fund has obtained investment funds from investors, the issue becomes how such funds can be invested by the fund. Neither the Securities Act nor the Regulations thereto attempt to deal with this issue. Rather, this is effected administratively through National Policy No. 39 of the Canadian Securities Administrators. ${ }^{39}$ The Policy, which sets out in detail how the Administrators will administer the provisions of the various provincial securities statutes applicable to mutual funds, does not attempt to set out the types of investments in which mutual funds are authorized to invest. Rather, it establishes general restrictions on the manner in which a fund may conduct its business. ${ }^{40}$ Primary amongst these restrictions are the following:

1. a fund may not hold more than $10 \%$ of its net assets in any class of securities of a particular issuer;

2. purchases of real estate and mortgages are restricted;

3. a fund may not hold more than $10 \%$ of its net assets in options, warrants or rights;

4. a fund may not purchase securities for the purpose of exercising control or management of an issuer;

5. a fund may not hold more than $10 \%$ of its total assets in gold or gold certificates;

6. a fund may not purchase or sell commodities or commodity futures other than cash or gold;

7. a fund may not invest in other mutual funds unless conflicts of interest are dealt with, duplication of management fees and sales charges is avoided, and the units purchased are qualified for distribution in Canada; or if the purchase is effected in order to invest in foreign securities through such a fund and disclosure is made thereof;

8. a fund may only borrow up to $5 \%$ of its net assets and only as a temporary measure;

9. a fund may not purchase securities on margin or sell securities short;

10. a fund may not hold more than $10 \%$ of its net assets in illiquid investments;

11. a fund may not purchase securities which require it to make payments in addition to the purchase price; and

Ibid. Parts 15 and 16.

39. National Policies are policy statements which are adopted by representatives from the various provincial securities regulatory authorities. They do not have force of law, but set out administrative guidelines and thus represent the law in a practical sense. Funds incorporated at the federal level may also have to comply with the provisions of the Investmem Companies Act, R.S.C. 1985, c.I-22, as amended.

th. Sec sections 2.04 and 2.05 of National Policy 39. The Canadian Securities Administrators have published draft amendments to National Policy 39 for public consultation. These amendments include a liberalization of the investment restrictions applicable to mutual funds, which allow mutual funds to invest in derivative products. 
12. a fund may not lend money (other than debt obligations) or guarantee obligations of any other person.

The restrictions set out above are intended to ensure that funds assets are not dissipated through speculative activities and that a minimum level of diversification is achieved. In contrast to the approach taken to other institutions, no attempt is made to ensure a minimum level of quality with respect to the investments themselves. This regulatory approach clearly allows mutual funds to adopt a higher level of risk than pension funds, for example. This is also true vis-a-vis the other institutions considered below. Given that mutual funds involve the discretionary funds of investors investing by way of private and voluntary transactions, effected in compliance with the prospectus and registration requirements of the Securities Act, it is difficult to see any economic or other policy basis for further regulating this aspect of institutional investment in order to ensure that mutual funds adopt a lower overall level of risk in their portfolios.

\section{INSURANCE COMPANIES}

Section 94 of the Insurance $A c t^{41}$ maintains that an insurance company incorporated under the laws of Alberta may only invest its funds in the manner specified therein. In the main, the specified investments are broadly similar to those prescribed for private sector pensions. One distinction is that insurance companies are also generally able to invest in securities issued by or associated with the government of a country where they are carrying on business. Insurance companies are also able to invest in government bonds of most commonwealth countries and the U.S.A. Preferred share and common share investments are subject to a higher five year earnings and dividend test and real estate investments are restricted to Alberta or other countries where the company is carrying on business. Specific Canadian resource property, real estate corporation, resource property corporation and mutual fund investments are not provided for. A 7\% of book value basket clause has no restrictions other than that no more than $.5 \%$ of the book value of assets may be invested in any one parcel of real estate. ${ }^{42}$

Important diversification requirements are also imposed on insurance companies. Other than with respect to securities guaranteed by a government, an Alberta insurance company may not hold more than $10 \%$ of its funds in the securities of a particular issuer or hold more than $10 \%$ of any issue of shares of any one issuer. In addition, an Alberta insurance company may not hold more than $25 \%$ of the book value of its assets in common shares nor more than $5 \%$ of the book value of its assets in real estate.

\section{E. TRUST CORPORATIONS}

Trust corporations are a hybrid entity in that while fiduciary activities have provided the traditional foundation of their business, one of the largest aspects of their business in a modern context surrounds taking deposits and redeploying such funds. As of March 30, 
1990, 43 trust corporations were registered in Alberta, of which 5 were incorporated in Alberta. Collectively they held $\$ 76.7$ billion in deposits and $\$ 81.9$ billion in assets. ${ }^{43}$ The current savings and loan debacle in the United States highlights the need to carefully consider the regulatory environment applicable to trust corporations, given their broad similarity to the American savings and loan company.

The Loan and Trust Corporations $\mathrm{Act}^{44}$ is a recent arrival to the regulatory landscape in Alberta having only been generally proclaimed into force on January 16, 1992. The Loan and Trust Corporations Act does not repeal its predecessor, the Trust Companies $A c t,{ }^{45}$ but requires trust companies organized under the Trust Companies Act to apply to continue under the Loan and Trust Corporations Act within one year of its coming into force. ${ }^{46}$ In view of the waning applicability of the Trust Companies Act and the fact that it adopts a qualitative legal list of investments only slightly less restrictive than that applicable to private sector pension funds, ${ }^{47}$ only the investment provisions of the Loan and Trust Corporations Act will be considered in detail here.

It is important to recognize that the Loan and Trust Corporations Act does not apply to the investment by trust corporations of funds held by them as fiduciaries. ${ }^{48}$ Funds held in a fiduciary capacity, other than deposits, must be invested in the manner prescribed by the Trustee Act. ${ }^{49}$ The Loan and Trust Corporations Act does apply to the investment of deposits and other monies not held in a fiduciary capacity by a trust corporation, and in this area it has fundamentally altered the regulation of institutional investment in Alberta by adopting the following general prudent investment standard:

196(1) A provincial corporation shall adhere to prudent investment standards in making investment decisions and in managing its total investments.

(2) For the purposes of this Act, prudent investment standards are those which, in the overall context of an investment portfolio, a reasonably prudent person would apply to investments made on behalf of another person with whom there exists a fiduciary relationship to make such investments without undue risk of loss or impairment and with a reasonable expectation of fair return or appreciation.

The prudent investment standard adopted in the Loan and Trust Corporations Act does not exist in a vacuum. The following principal restrictions and parameters are grafted onto the standard:

1. An investment committee is required to be formed to establish policies and procedures to ensure that the trust corporation applies prudent investment 
standards in making investment decisions and in managing its total investments. $^{50}$

2. Liquidity requirements are established which require at least $45 \%$ of a trust corporation's assets be held in investments such as Government of Canada or a Province of Canada securities, banker's acceptances or cash. ${ }^{51}$

3. Loans or investments in respect of any one person or connected persons may not exceed a prescribed amount. ${ }^{52}$

4. Other than with respect to corporations in broadly related industries, a trust corporation may not generally hold more than $10 \%$ of the voting shares of a corporation. $^{53}$

Subject to compliance with the above prudent investment standard, the Loan and Trust Corporations Act also permits trust corporations to make personal loans not exceeding prescribed amounts and commercial loans not exceeding 5\% of the total assets of the trust corporation. A trust corporation may also invest in mortgages in respect of improved real estate in Canada not exceeding 75\% of the value of the property, or mortgages otherwise insured by Alberta, Canada or a Canadian insurance corporation, and may also invest in improved real estate in Canada up to prescribed limits.

The flexibility provided by the general prudent investment standard clearly distinguishes it from the qualitative legal list regime. As will be discussed in greater detail below, the constraints imposed by the qualitative legal list raise one of the major question marks related to the current regulatory regime for institutional investment in the Province of Alberta. The approach taken by the Loan and Trust Corporations Act puts clearly into focus the question of whether or not a general prudent investment standard should become the guiding norm for the regulation of institutional investment in Alberta.

\section{F. TRUSTEES}

The Trustee $A c t^{54}$ permits a trustee to invest trust monies in a qualitative legal list of investments, provided such investments are in all other respects reasonable and proper. In the main, the prescribed list is much narrower than that for private sector pensions, excluding from the fixed income category philanthropic corporation bonds backed by provincial subsidies; 10 year seasoned secured bonds; bonds of infrastructure authorities; mortgage investment company debentures; insurance company insured bonds; bonds secured by transportation equipment and corporate bonds issued or guaranteed by corporations having stable earnings or low debt/capitalization ratios. Common shares are required to have a full five year earnings or dividend track record. $75 \%$ loan to value and

Loan and Trust Corporations Act, supra, note 3 s. 197.

st. Ibid. s. 198, and the Loan and Trust Corporations Regulation, Alta. Reg. 171/92, s. 22.

32. Ibid. s. 204.

s3. Ibid. s. 207, and Alta. Reg. 171/92, s. 24.

s. Supra, note 8, s. 5 . 
insured mortgages are also authorized. Given the absence of the incorporation by reference of federal statutory provisions, it is surprising to see that securities issued by various provincial government agencies or related entities are not authorized, other than the shares of the Alberta Energy Company. Real estate investments are not authorized. A trustee is also restricted from investing more than $15 \%$ of the current market value of the trust fund in common shares and from investing more than $35 \%$ of the current market value in preferred shares and secured corporate debt.

The common law of trusts has traditionally favoured conservative investments geared towards preservation of capital. The Trustee Act has largely codified this common law heritage, and it is not surprising, therefore, to observe a narrowly circumscribed list limited to high quality instruments emphasizing preservation of capital.

\section{G. CREDIT UNIONS}

Credit Unions are located throughout the Province of Alberta, although perhaps disproportionately in rural areas. They accept deposits and largely recycle the deposits into mortgages and other loans to members of the credit union. As with trust corporations, they appear in many respects like a bank, but do not provide nearly the range of services. Unlike trust corporations, they do not directly offer fiduciary services. Their existence in Alberta is probably attributable to some combination of the needs of smaller communities, populism, and federalism. Although they are very decentralized and do not have the same impact as other institutions, credit unions need to be considered in order to properly survey and understand Alberta's institutional make-up. As of March 30, 1990 there were 97 Credit Unions in Alberta collectively holding $\$ 2.93$ billion in deposits and $\$ 3.03$ billion in assets. ${ }^{55}$

Following large losses in the early and mid 80's, Alberta credit unions were reorganized by the Province of Alberta, and a new Credit Union Act ${ }^{56}$ was brought into force in 1989. Perhaps not surprisingly, given the immediate past history, severe restrictions are placed on the investment activities of credit unions. Except where needed to carry on business, or pursuant to the realization of security, a credit union may not acquire land, ${ }^{57}$ and is otherwise prohibited from acquiring securities, unless such securities are specifically authorized. ${ }^{58}$ A prudent investment standard, identical to that discussed above in relation to the Loan and Trust Corporations Act is adopted. ${ }^{59}$ Securities of the Central Credit Union organization, Canada, a Province of Canada, municipalities, hospital districts, deposits with any Canada Deposit Insurance Corporation insured institution and a $2 \%$ of consolidated assets general basket clause are prescribed as the only authorized investments. ${ }^{60}$

$\begin{array}{ll}\text { ss. } & \text { Supra, note } 43 . \\ \text { s6. } & \text { Supra, note } 3 . \\ \text { s7. } & \text { Ihid. s. } 98 . \\ \text { sk. } & \text { Ihid. s. } 99 . \\ \text { s9. } & \text { Ibid. s. } 100 . \\ \text { ๓o. } & \text { Ibid. s. } 101 .\end{array}$


The most interesting aspect of the regulation of credit union investment is the qualified use of the prudent investment standard. Reading all of the above provisions together, one could reasonably conclude that a credit union may not invest in any securities unless such securities are specifically authorized and that a credit union must otherwise discharge the prudent investment standard. This suggests that a credit union can only invest in, and will only be deemed to be acting prudently, if it restricts investments to the specifically authorized items. As will be discussed below, such an approach defeats the purpose of the adoption of the general prudent investment standard, and amounts to little more than a gloss on the common law prudential standard that would apply to any investment made on the basis of a qualitative legal list regime.

\section{H. ALBERTA HERITAGE SAVINGS TRUST FUND}

In the realm of institutional investment in Alberta, the Alberta Heritage Savings Trust Fund ("AHSTF") is somewhat of a different kettle of fish, involving public as opposed to private funds. However, given the size (both perceived and real) ${ }^{61}$ of the AHSTF and its resulting visibility and impact in the market place, it is important for substantive and comparative reasons to consider briefly how it is permitted to invest its funds.

Under the Alberta Heritage Savings Trust Fund Act, ${ }^{62}$ the assets of the AHSTF are to be used for the following purposes:

1. Capital Projects: Investments in projects which will provide long term economic or social benefits to the people of Alberta but which may not necessarily by their nature yield a return to the AHSTF.

2. Canadian Investments: Investments by way of loans to, or guaranteed by, the Crown in right of Canada or the Crown in right of any other Province of Canada.

3. Alberta Investments: Investments which, in the opinion of the Investment Committee or in the opinion of the Legislative Assembly, will yield a reasonable return or profit to the AHSTF and will tend to strengthen or diversify the economy of Alberta.

4. Energy Investments: Investments which, in the opinion of the Investment Committee, or in the opinion of the Legislative Assembly will yield a reasonable return or profit to the AHSTF and will facilitate the development, processing or transportation of energy resources within Canada. 
5. Commercial Investments: Investments which, in the opinion of the Investment Committee, or in the opinion of the Legislative Assembly will yield a commercial return or profit to the AHSTF.

Based on the above terms, Capital Projects may not exceed $25 \%$ of the assets of the AHSTF and Canadian Investments may not exceed $20 \%$ of the assets of the AHSTF. There is no requirement that the balance of the AHSTF be allocated among Alberta Investments, Energy Investments and Commercial Investments. Commercial Investments are, however, required to be made in accordance with the prescribed legal list set out in the Alberta Heritage Savings Trust Fund Act, which includes corporate issues authorized on May 31, 1992 under section 86 of the Canadian and British Insurance Companies Act. ${ }^{63}$ The result, with respect to this aspect of the AHSTF, is a group of authorized investments very similar, but slightly narrower than that permitted for private sector pensions. Insurance company insured bonds, and certain other insurance company related instruments are not permitted in the fixed income category. Canadian resource properties, real estate corporations and Canadian resource corporations are also not included. These limitations must, however, be balanced against the overwhelmingly political nature of the AHSTF. In that the AHSTF is not required to allocate any investments to the Commercial Investments category, the disposition of the entire AHSTF is in reality left to the immediate discretion of the Investment Committee ${ }^{64}$ (which includes all members of the Executive Council).

\section{REGULATION IN ALBERTA - AN EVALUATION}

When one stands back and examines the system of regulation of institutional investment described above, it is clear that the regime applicable to pension funds, insurance companies, trustees, credit unions and Commercial Investments of the AHSTF are broadly similar, incorporating a qualitative legal list standard. Mutual funds, trust corporations and the non-Commercial Investments of the AHSTF are somewhat different.

In view of their broad similarity, the balance of this paper will discuss some of the issues and implications associated with the regulatory standards applicable to pension funds, insurance companies, trustees, credit unions and Commercial Investments of the AHSTF. As discussed in the mutual funds section above, given the private and discretionary nature of mutual funds and existing securities law protections, there would appear to be little justification for additional regulation in this area. It is also not proposed to analyze the regime applicable to the non-Commercial Investments of the AHSTF given the scope of such an issue. The potential impact of the AHSTF and the broader social and economic questions associated with the AHSTF are simply beyond the scope of this paper. The prudent investment standard applicable to trust corporations will be discussed in large measure as part of the general evaluation below of the qualitative legal list standard. 


\section{A. THE QUALITATIVE LEGAL LIST}

An initial examination of the qualitative legal list approach to regulating institutional investment discussed above discloses a complex and technical set of rules that differ considerably as between various institutions, but which have as their primary focus the avoidance of capital loss. Lawyers working in this area will be familiar with the considerable efforts and frustrations that are encountered in many transactions in determining whether or not the securities in question are eligible for investment by a particular institution and of the countless hours taken up in the preparation of legal opinions and supporting certificates speaking to the various financial tests. Given the nature of these rules, and the efforts expended to ensure compliance, it may be viewed as surprising to suggest that they may not effectively achieve the goal of ensuring the safety of the capital value of investments. In reality, the fact that the rules are so technical ultimately means that lawyers involved with transactions are constrained only by their ingenuity in designing frameworks which will allow the securities in question to attain technical eligibility status. Incubation of corporations, acquisition of special purpose corporations, guarantees from specially constructed corporations and various forms of arrangements are just some of the steps which can and have been taken to ensure technical compliance with eligibility statutes. ${ }^{65}$ A meaningful evaluation of many of such vehicles would likely show that, notwithstanding investment eligibility, the securities in question would be no less risky than blind pools or junk bonds.

Studies in this area have also concluded in the following terms that the eligibility rules do not achieve their underlying financial goals:

the major conclusion of this study is that equity eligibility rules, such as the current $4 \%$ rules and variants thereof, have little impact on the risk, return and return-to-risk characteristics of pension fund portfolios.

Thus, there seems to be little financial justification for the continued existence of such rules. ${ }^{66}$

Further examination of the qualitative legal list approach to regulating institutional investment also discloses a number of larger principles and implications. ${ }^{67}$ First, the qualitative test is made with respect to particular securities and not the portfolio as a whole. Second, no consideration is given to the potential returns which may be available from particular investments, with the result that no attempt is made to balance risk and return. These characteristics have led several observers to criticize the qualitative legal list as being incompatible with the use of modern portfolio theory. ${ }^{68}$

Incubation refers to a technique where a corporation is incorporated and placed on the shelf, but capitalised in a manner that it will earn $4 \%$ for the required 4 or 5 year time period. After this time, the corporation is sold and utilized as the issuing vehicle. Depending on market conditions, these corporations have been known to sell for many thousands of dollars. Canadian Evidence" 4:6 Canadian Journal of Insurance Law at 90-96.

67. For a larger discussion of some of these principles see: Note, "The Regulation of Risky Investments" (1970) 83 Harvard Law Review 603. 


\section{B. MODERN FINANCE THEORY}

Much has been written on modern portfolio theory and its relationship to the legal standards governing portfolio management. ${ }^{69}$ Modern portfolio theory in its simplest terms suggests that the expected value of a portfolio is the sum of the expected values of its constituent securities, which in turn are the sum of the products of each expected value for the security and the probability of such expected value occurring. The most desirable portfolio for any expected value is the portfolio with the lowest risk. The portfolio having the lowest expected variance from the expected value is viewed as having the lowest risk. Vis-a-vis a portfolio, the theory points out that as important as the variance of particular securities is the co-variance of the securities among themselves. Securities which strongly "co-vary" among themselves have the ability to reduce the overall risk of the portfolio.

Co-variance among securities is thus a key to risk reduction through diversification. A diversification strategy of this sort can allow a portfolio to remove non-systematic risk, or risk that is unrelated to the market itself. The ability to diversify away non-systematic risk provides the essence of modern portfolio theory. It is for this reason that it has been suggested that investors are only compensated for the level of risk that their portfolio bears to the market risk as a whole, the higher the level of systematic risk of the portfolio, the higher the expected return of the portfolio.

Viewed in this sense, the unsuitability of security by security analysis to modern portfolio theory is apparent. The issue is not the absolute quality of each security, but rather how that security influences the risk of the portfolio as a whole. As importantly, the fundamental policy and regulatory issue becomes not setting standards for individual securities, but setting standards for the portfolio as a whole, and determining what level of risk is appropriate for a particular portfolio.

\section{PRUDENT INVESTMENT STANDARDS}

Prudent investment standards have been developed in large measure as a response to the limitations of the qualitative legal list. The prudent investment standard is not, however, without its critics. One criticism stems from the judicial evolution in the United States of the standard subsequent to its derivation in the 1830 decision of the Supreme Judicial Court of Massachusetts in Harvard College v. Amory. ${ }^{70}$ In Harvard College, the English rule requiring investment in government securities was rejected in favour of a rule which required trustees "to observe how men of prudence, discretion and intelligence manage their own affairs, not in regard to speculation, but in regard to the

See: Gordon, ibid.; J.N. Gordon \& L.A. Kornhauser, "Efficient Markets, Costly Information and Securities Research" (1985) 60 New York University Law Review 761; R.A. Brealcy, An Introduction to Risk and Return from Common Stocks (Cambridge, Mass: MIT Press, 1983); R.A. Posner, Economic Analysis of Law (Boston: Little, Brown \& Co., 1977); Bines, ibid.; Harvard Law Review Note, supra, note 67. 
permanent disposition of their funds, considering the probable income, as well as the probable safety of the capital to be invested."

The prudent investment standard thus formulated has been adopted by decision or statute in most United States jurisdictions. The difficulty is that subsequent courts have interpreted the Harvard College decision to require preservation of the estate as the established norm for persons who are safeguarding property for others. Gordon has described this evolution as producing the same types of restrictions which flow from the use of a qualitative legal list:

The effect of the constrained prudent man rule is to inhibit trustee investment in investment vehicles and instruments that did not exist a generation ago, that prudent persons now believe to enhance effective trust fund management, that are arguably analogous to forbidden investments. For example, a trustee may be unable to obtain optimum portfolio diversification because it cannot invest in unseasoned securities or stocks that do not pay dividends. It may be difficult for a trustec to participate in a venture capital pool. even one that invests across a wide spectrum because of the case against new and untried enterprises... or a trustee may be unable to participate in certain real estate investment pools because the form of the investment looks subordinated (like the forbidden second mortgage), even though a permissible first mortgage construction lien may in fact present much greater risk. Similarly, a trustee may be prohibited from acquiring or forced to divest discount bond (known today as junk bonds), even though a well diversified pool of such bonds may provide a greater retum for the risk than gilt edged bonds.

A trustee may also be unwilling to use options as a hedge against adverse stock market movements because of the likelihood that a Scot influenced court will regard such instruments as speculative, even though appropriate use of options may provide, at a lower cost, the same economic protection as strategies that are legally unassailable. Similarly, futures look speculative and involve purchases on margin, yet appropriate futures transactions can lower exposure to fluctuating interests rates.

In sum, if prudence embodies the idea of earning the maximum possible return for the chosen level of risk, then a modern trustee is constrained to act imprudently."

Without some guidelines attached to the prudent investment standard, there is clearly a risk that courts will interpret the notion of prudence with an eye to past determinations in this area and interpret the notion of prudence in accordance with the qualitative legal list standard.

Another criticism of the prudent investment standard suggests that one of the most important underlying aspects of the trust is an efficient reduction of beneficiary monitoring costs through the use of the rigorous fiduciary principal. ${ }^{72}$ Without more, a prudent investment standard will not distinguish between the wants and needs of various beneficiaries. Stated in more technical terms, different beneficiaries will have different risk preferences. There is no doubt that there is a class of beneficiary, who simply want to know that the property in question will more or less be there when they need it. Their

72. A.I. Ogus, "The Trust as Governance Structure" 36 U. T. L. J. 186 at 207. 
interests may be somewhat different than a long term beneficiary under a pension plan whose benefits can likely be substantially enhanced through the use of modern portfolio theory and other investment techniques which would be permitted under the prudent investment standard. This criticism would seem to reinforce the need to establish and attach standards and guidelines to the prudential standard in order to ensure that all beneficiaries are provided with a modicum of certainty that their particular goals will be achieved.

Related to the question of beneficiary monitoring is the suggestion that the prudent investment standard would establish too permissive a standard for the evaluation of trustee behaviour. It has been suggested that the rule might amount to a business judgement rule for trustees, which might insulate them from liability for their investment decisions. Under the prudent investment standard, courts would be called upon to evaluate complex investment strategies taken as a whole, as opposed to focusing on investment by investment analysis. Battles of the experts could clearly come into play. Gordon, however, rejects this view, and suggests that the prudent investment rule properly understood would include a rule of caution and that:

\begin{abstract}
...an unconstrained prudent man rule would recognize that the trustee must construct and maintain a portfolio of appropriate risk for the trust. The trustee must use reasonable care (including the appropriate level of skill), but he should be able to use any investment vehicle or technique reasonably calculated to maximize expected returns for the permitted risk and minimize the transaction costs. Assuming undivided loyalty, due caution in selecting a portfolio risk level and due care in managing the portfolio consistent with the permitted risk, the trustee should be free from liability for particular investment decisions that turn out badly. The insight of portfolio theory is that the duty of caution comes into play in the selection of the appropriate portfolio risk level, not as a bar to reasonable means of investing in light of the allowed risk. $^{73}$
\end{abstract}

The questions of judicial interpretation, beneficiary certainty and enforcement raised by a move to a general prudent investment standard, really focus on designing a legal form that will allow for a general prudent investment standard, but provide guidelines establishing investment goals and policies and certain minimum requirements for the specific entity in question. This simply acknowledges the proposition that "prudence as it relates to pension fund governors has meaning only in relation to the specific pension deal." ${ }^{174}$ The question really becomes one of designing a generally applicable legal standard, which provides enough flexibility to require and allow individual needs to be met. These questions have been confronted and dealt with in other jurisdictions and their treatment of these issues is most instructive in the current context.

\title{
D. RECENT DEVELOPMENTS
}

In recent years, a number of jurisdictions have moved to adopt prudent investment standards. One of the first steps in this direction was the Employee Retirement Income

Ontario Task Force on the Investment of Public Sector Pension Funds, In Whose Interest? (Toronto: Queen's Printer, 1987) at 90. 
Security Program of $1974^{75}$ in the United States. More recently, we have seen similar initiatives in the Provinces of Ontario, ${ }^{76}$ Quebec, ${ }^{77}$ and British Columbia. ${ }^{78}$ Generally, each of these enactments sets out a broad prudent investment standard and grafts on requirements such as diversification standards and the filing of documents and instruments which will govern the entity and speak to its investment goals. As discussed above, this is the approach taken in the Alberta Trust and Loan Corporation Act. ${ }^{79}$ The federal government has also moved in this direction in the new Bank Act, ${ }^{80} \mathrm{Co}$-operative Credit Associations Act, ${ }^{81}$ Insurance Companies Act ${ }^{82}$ and Trust and Loan Companies Act. ${ }^{83}$

As provincial legislation, the Ontario Pension Benefits Act, 1987 and the British Columbia Financial Institutions Act are directly relevant, and are particularly important in view of the likely homogenizing national effect the Ontario legislation will have ${ }^{84}$ and because of the move by the B.C. legislation to rationalize the law in this area across a range of institutions. The regime adopted under the Ontario Pension Benefits Act, 1987 incorporates a prudent investment standard, but requires each fund to adopt, file and adhere to a statement of investment policies and goals speaking to diversification and asset mix, etc., subject to the following principle general rules:

1. Investments must be made with consideration given to the overall context of the investment portfolio without undue risk of loss or impairment and with a reasonable expectation of fair return or appreciation given the nature of the investment.

2. Not more than $10 \%$ of a fund may be invested in any one issuer.

3. Not more than $25 \%$ of the fund in the aggregate may be invested in real estate and resource properties directly or indirectly, subject to $10 \%$ in any one corporation, $15 \%$ in the aggregate in resource properties and $5 \%$ in any one real estate project.

4. A fund may not hold more than $30 \%$ of the shares in any one corporation unless it is a special purpose corporation.

5. Mortgage investment restrictions similar to those for private Alberta pension funds are incorporated.

29 U.S. Code 1001 et seq.

Pension Benefits Act. 1987, S.O. 1987, c. 35, as amended; and the Loan and Trust Corporations Act. 1987, S.O. 1987, c. 33, as amended.

Supplemental Pension Plans Act, S.Q. 1989, as amended.

Financial Institutions Act, S.B.C. 1989, c. 47 as amended.

Supra, note 3.

S.C. 1991 , c. 46, s. 465 .

S.C. 1991 , c. 48, s. 387.

S.C. 1991 , c. 47, s. 492.

S.C. 1991 , c. 45 , s. 450 .

For example, pursuant to ss. 2(i)(a) of the Employment Pension Plans Regulation, supra, note 11, Ontario is recognized for various purposes as a jurisdiction having substantially similar legislation to that in Alberta. 
6. Self dealing restrictions are imposed.

7. Borrowing is prohibited except for short term emergency purposes. ${ }^{85}$

The British Columbia Financial Institutions Act adopts a prudent investment standard which is applicable to provincially regulated credit unions, trust companies and insurance companies. ${ }^{86}$ In general terms, the directors of each of these financial institutions are required to appoint or elect an investment and loan committee which must recommend a written investment and lending policy. ${ }^{87}$ A financial institution is then required to adhere to prudent standards in making investments and loans and conducting various other activities and is prohibited from making investments or loans other than ones that are consistent with the investment and lending policy and the general investment provisions established including the following:

1. Investments and loans shall be made without undue risk of loss and with a reasonable expectation of a fair return.

2. A financial institution may not acquire more than $10 \%$ of the voting shares in a corporation or more than a $10 \%$ interest in any entity.

3. A credit union may not lend more than $\$ 25,000$ under any single commercial loan.

4. Credit unions and trust companies may not hold more than $10 \%$ of their assets in land.

5. A trust company must have at least $20 \%$ of its assets composed of prescribed liquid assets such as cash and government securities.

\section{Related party transaction restrictions are imposed. ${ }^{88}$}

The above British Columbia provisions, and the similar albeit more stringent provisions contained in the Loan and Trust Co-operations Act, ${ }^{89}$ raise the issue of whether or not it is appropriate for deposit taking institutions to independently establish investment plans, subject to such overriding constraints. Depositors are clearly affected by such plans, yet have no input into the plans, and likely have little awareness of the different risk profiles of various institutions. ${ }^{90}$ Whether or not such general constraints on investment activity deal sufficiently with the interests of depositors and establish appropriate risk parameters

ks. Pension Benefits Act, 1987, supra, note 76, s. 20 and Ontario Regulation 708/87.

86. Supra, note 78, s. 1.

s7. Ibid. s. 133 and 134.

88. Ibid. s. 136 and Part 5 and Regulation to the Financial Institutions Act, B.C. Order in Council No. 1354 and 1356.

*4. Supra, note 3.

41. The existence of Canada Deposit Insurance Corporation deposit insurance may also be relevant to the risk profile of a member financial institution in that pursuant to subparagraph 11(2)(e) of the Canada Deposit Insurance Corporation Act, R.S.C. 1985, e.C-3, as amended, the board of directors of the Canada Deposit Insurance Corporation is authorized to make by-laws prescribing standards of sound business and financial practices for member institutions. 
is not at all clear. The Ontario Loan and Trust Corporations Act, ${ }^{91}$ in contrast, establishes more stringent risk parameters. It imposes a general prudent investment standard, and diversification requirements, but goes on to require that $50 \%$ of the corporation's assets be invested in instruments such as Canada or province of Canada bonds. $^{92}$

Recent judicial decisions also suggest that a different judicial approach is being taken to investment matters. Although there have been no recent Canadian decisions of significance in this area, recent decisions in England have evidenced an increasing sophistication and familiarity with the policy principles underlining the prudent investment standard. Particularly instructive is the decision in Nestle v. National Westminster Bank $P L C^{93}$ where Mr. Justice Hoffman suggested that modern trustees acting within their investment powers are entitled to be judged by the standard of current portfolio theory and adopted the following passage:

\footnotetext{
The difficulty - perhaps sheer impossibility - of satisfying both (tenant for life and remainderman) is reflected in the fact that there is no such thing as an authentic proper balance; although it would be easy enough to say that the fund is unbalanced in extreme cases, there must be a wide band in the middle, so to speak, where there is room for genuine difference of opinion. An opinion on this subject will reflect a view taken of the present state of the market, the prospect of both fixed interest stocks and equities in the future, and the present and future circumstances of the beneficiaries. Clearly an equation containing so many variables is not going to resolve itself into an inevitable solution.
}

Another very significant decision for the range of issues considered and rules established is the English Court of Appeal's decision in Cowan v. Scargill. ${ }^{94}$ This decision involved the mine workers' pension fund, which was a fund jointly administered by the National Coal Board and the Union. Union representatives refused to consent to an investment policy that did not restrict overseas investments, require divestment of overseas investments and prohibit investments in energy corporations competing with coal. The court ultimately held that a decision by trustees to limit investment powers otherwise available to them by law would generally violate the fiduciary duty of prudence. In addition the court held that:

1. The best interests of beneficiaries are normally their financial interests.

2. The power of investment must be exercised so as to yield the best return for the beneficiaries judged in relation to the risk of the investment in question.

3. Trustees are normally open to criticism if they fail to make a particular investment for social or political reasons.

9. Supra, nole 76 .

92. Ibid. s. 167.

93. Unreported June 29, 1988.

*. [1984] 2 All E.R. 750. Aspects of this decision have been adopted and applied in two Canadian cases: BOE v. Alexander (1987), 41 D.L.R. 4th (B.C.C.A.) and McCreight v. 146919 Canada Lid., (Unreported, Ontario High Court, February 1, 1991). 
4. Trustees must put aside their own personal interests and views in considering what investments to make.

5. The standard required of trustees is such that they must seek advice on matters that they do not understand and on receiving such advice, must act with prudence.

\section{E. ADOPTION OF PRUDENT INVESTMENT STANDARDS}

The above decisions suggest that the judicial understanding of the concept of prudence is evolving, and that sensible interpretations of questions involving prudent investment standards that facilitate the underlying economic and policy foundations behind the standard are likely to emerge. This, coupled with the developments and trends throughout Canada and other jurisdictions, suggest that the Province of Alberta should build on the new Alberta Loan and Trust Corporations Act and move to rationalize the legal regime in this area to provide for prudent investment standards for all Alberta institutions, other than mutual funds and non-Commercial Investments of the AHSTF which, as suggested above, are in different categories.

If a move in this direction is undertaken, difficult public policy decisions related to the establishment of appropriate risk parameters for the various categories of institutions will have to be made. The different approaches surveyed above in respect of deposit taking institutions in B.C., Alberta and Ontario indicate there is room for disagreement as to the exact nature of risk parameters. They also indicate that there is a clear need to establish risk parameters and to otherwise take steps to ensure against speculation and other abuses through broad diversification and other standards. The fine tuning of these issues and other technical questions are best left to financial experts. With due regard to such technical financial issues, the Province of Alberta should be able to move to adopt an efficient and generally beneficial prudent investment standard for Alberta institutions.

\section{F. THE ROLE OF INSTITUTIONS}

As mentioned at the outset, it is the increasing dominance of institutional investors which provides the impetus for this examination of the regulatory frame work applicable to institutional investment. Questions of how institutions allocate capital and the role they play in the vehicles in which they invest have long caught the eye of many commentators in Canada and elsewhere. Some of the more critical of these observers have said:

...in effect, the position of the institutional managers is that they will not exercise their voting power so as to seriously affect the choice or the policies of corporate management. The individuals for whom the institutions are fiduciaries, holders of rights in pension trusts, of shares in mutual funds, or of insurance policies, have surrendered their voting power. The institutional managers, therefore, by their policy of non-intervention, merely insulate the corporate management from possible action by or influence of the ultimate beneficial owners of the stock. A policy of non action by the institutions means that directors 
and management of the corporations whose stock they hold become increasingly self appointed and unchallengeable: though it continues, it freezes absolute power in the corporate managements. ${ }^{95}$

For the past 30 years, the ownership of American public corporations has become increasingly concentrated, thus encouraging hopes that insurance companies, pension funds, investment companies and other institutional investors would, by taking an active role, protect not only their own interests but those of shareholders generally. All the ingredients seem to be there. They own large blocks of stock, some of them as much as $\$ 100$ million in a single company. They have the stance and the sophistication. As it turned out, however, the money managers have contributed almost nothing to the direction or oversight of the companies whose stock they so briefly hold. ${ }^{.6}$

Examples provided by the role of the Caisse de Depot in funding the Steinberg takeover and the role of institutions in facilitating the more recent Sherritt Gordon Mines and Memotec reorganizations draw home the significance of these questions in the context of the regulation of institutional investment in Canadian jurisdictions generally. ${ }^{97}$ These questions are equally applicable to Alberta institutions.

When one examines how the legal regime in Alberta deals with these larger social and economic questions, it is interesting to note that there exists very little in the way of regulation. In the main, institutions are treated in the same fashion as any large investor. There are no positive requirements on institutions to vote the shares that they hold or to otherwise take an active role in the vehicles in which they have invested. ${ }^{98}$ The only restrictions that one can find in the area, or provisions which in any way put institutions in a different class than other investors, are restrictions which prohibit institutions from positively exerting influence or control. These include restrictions applicable to private and public sector pension funds which prohibit holdings of more than $30 \%$ of the shares of any one corporation, ${ }^{99}$ the restriction applicable to mutual funds prohibiting purchases for the purpose of exercising control of the management of an issuer, ${ }^{100}$ the restriction limiting insurance companies to not more than $10 \%$ of any issue of any one corporation $^{101}$ and the restriction limiting trust corporations to $10 \%$ of the voting shares

A. Berle Jr., Power Without Property: A New Development in American Political Economy, (New York: Harcourt, Brace \& Co. 1959) at 55.

L. Lowenstein, What's Wrong with Wall Street: Short Term Gain and the Absentee Shareholder (New York: Addison-Wesley Publishing, Inc. 1987) at 57-58.

See: Globe \& Mail Report on Business (28 August, 1989) B1, (20 September, 1991) B1 and (15 \& 16 May, 1991) B1, 5, 6 and 9 respectively.

98. R. Monks and N. Minow in Power and Responsibility (New York: Harper, 1991) argue that obligations should be imposed upon institutions to vote their holdings and suggest that fiduciaries in the United States under the Employee Retirement Income Security Program 1974, (supra, note 75) who vote blindly, or do not vote on corporate issues, may be violating their duty to plan participants. It should be noted that the Securities Act (supra, note 4, s. 79) and National Policy 41 restrict certain institutions from voting shares which are held on behalf of other persons and impose obligations on institutions intended to ensure that voting rights are exercised by the beneficial holder of the shares. Supra, note 18, Schedule III, paragraph I(s)(iii) and note $32 \mathrm{ss.} \mathrm{86(n)(iii).}$

National Policy 39, ss. 2.04(8).

Supra, note 41, s. 94(14)(c). 
of another corporation. ${ }^{102}$ These restrictions limit the affected institutions' opportunity to take up strong control positions and otherwise influence management. The $30 \%$ restriction for pension funds has been defended on the grounds of ensuring that corporate control does not fall into the hands, of a few institutions. ${ }^{103}$ The rule obviously bears no relationship to the institutions portfolio and reinforces the passive role of institutions.

The larger economic and social policy questions raised by the above rules, which deny Alberta institutions the opportunity to participate in the market for corporate control, but which do not require institutions to vote in respect of or otherwise involve themselves with their investment vehicles, are beyond the scope of this paper. The increasing importance of these issues should, however, be recognized. It is possible that Alberta may be out of step with the emerging trends in the United States which look to ensure that institutions participate in the vehicles in which they have invested, and with prevailing standards in jurisdictions outside of Canada and in other parts of Canada which do not severely restrict an institutions holdings in a particular entity. It should be expected that these issues will find their way onto the public policy agenda in many jurisdictions and should be similarly subject to vigorous debate in Alberta. At a minimum, the issue has to be addressed directly or indirectly in the design of prudent investment criteria if a larger move is made to a general prudent investment standard for institutions.

\section{CONCLUSION}

This paper has summarized in very general terms the law relating to institutional investment in Alberta. The first level of regulation is through the common law and laws of general application which impose various fiduciary, corporate, contractual and general regulatory obligations upon institutions. The primary level of regulation, however, is statutory. Statutory provisions generally regulate institutional investment by establishing prescribed lists of instruments in which an institution is permitted to invest its funds. The only exceptions to this approach are mutual funds, non-Commercial Investments of the AHSTF, and more recently, trust corporations.

While the prudent investment standard approach to institutional investment poses significant regulatory problems in establishing appropriate risk parameters, it has been suggested that the Province of Alberta should move to rationalize its approach to institutional investment by adopting such standards for all institutions. The questionable effectiveness of the qualitative legal list standard, the conflict between the legal list approach and modern portfolio theory, the clear thrust towards the prudent investment standard in other jurisdictions and the emerging judicial comprehension of the standard provide clear evidence of the need to move in this direction.

At present, Alberta does not treat institutions differently than any other large investors and imposes no specific obligations on institutions in the area of corporate governance. Given the enormous changes in the financial market place in recent years, and the special 
needs of Alberta based enterprises for capital, the question of the role of institutions in the Alberta market place should be considered in depth in order to determine if the appropriate economic and social balance has been structured.

Moves in the above directions should help to ensure that Alberta institutions better serve the needs of their beneficiaries, others interested or dealing with them and the general economic needs of the Province of Alberta. 


\begin{tabular}{|c|c|c|c|c|c|c|c|c|}
\hline Description & \begin{tabular}{|l} 
Private \\
Sector \\
Pensions
\end{tabular} & \begin{tabular}{|l} 
Public \\
Sector \\
Pensions
\end{tabular} & $\begin{array}{l}\text { Mutual } \\
\text { Funds }\end{array}$ & $\begin{array}{l}\text { Insurance } \\
\text { Co's }\end{array}$ & $\begin{array}{l}\text { Trust Corps. } \\
\text { (deposits and } \\
\text { investments) }\end{array}$ & Trustees & $\begin{array}{l}\text { Credit } \\
\text { Unions }\end{array}$ & $\begin{array}{l}\text { Heritage } \\
\text { Savings } \\
\text { Trust Fund }\end{array}$ \\
\hline $\begin{array}{l}\text { Fixed Income Investments } \\
\text { Bonds, debentures, stocks etc. of } \\
\text { or guaranteed by Canada, a } \\
\text { Province of Canada or any } \\
\text { country where the employer is } \\
\text { carrying on business }\end{array}$ & $\begin{array}{l}\quad \mathrm{X} \\
\text { (subject to 5\% } \\
\text { of book value } \\
\text { of assets in } \\
\text { other } \\
\text { countries) }\end{array}$ & $\begin{array}{l}\quad \mathrm{X} \\
\text { (also countries } \\
\text { other than } \\
\text { Canada) }\end{array}$ & $\mathbf{X}$ & \begin{tabular}{l}
\multicolumn{1}{c}{$\mathrm{X}$} \\
(only provinces \\
where carrying on \\
business, but also \\
Australia, Sri \\
Lanka India, N.Z. \\
South Africa \\
Pakistan, UK and \\
colonies \\
Zimbabwe, \\
Ireland, US and \\
US States)
\end{tabular} & $\mathbf{X}$ & \begin{tabular}{l}
\multicolumn{1}{c}{$\mathrm{X}$} \\
(also UK or \\
USA)
\end{tabular} & $\mathrm{X}$ & $\begin{array}{r}\mathrm{X} \\
\text { (and other } \\
\text { countries) }\end{array}$ \\
\hline $\begin{array}{l}\text { Bonds, debentures, etc. of or } \\
\text { guaranteed by a municipal or } \\
\text { school corporation in Canada, or } \\
\text { otherwise fully secured by taxes } \\
\text { levied under the authority of a } \\
\text { province }\end{array}$ & $\mathrm{X}$ & \begin{tabular}{l}
\multicolumn{1}{c}{$\mathrm{X}$} \\
(Also various \\
Alberta \\
administrative \\
authorities)
\end{tabular} & $\mathrm{x}$ & $\begin{array}{l}\quad \mathrm{X} \\
\text { (also municipal } \\
\text { corps and school } \\
\text { corps where } \\
\text { carrying on } \\
\text { business) }\end{array}$ & $\mathrm{x}$ & $\begin{array}{l}\quad \text { X } \\
\text { (Alberta } \\
\text { school, } \\
\text { drainage and } \\
\text { Hospital } \\
\text { authorities } \\
\text { only) }\end{array}$ & \begin{tabular}{l}
\multicolumn{1}{c}{ X } \\
(Alberta only, \\
but also \\
hospital \\
districts)
\end{tabular} & $\mathbf{x}$ \\
\hline $\begin{array}{l}\text { Bonds or debentures of a } \\
\text { corporation secured by the } \\
\text { assignment of an adequate Govt. } \\
\text { of Canada annual payment }\end{array}$ & $\mathrm{x}$ & $\mathrm{x}$ & $\mathrm{x}$ & $\mathrm{x}$ & $\mathbf{X}$ & \begin{tabular}{l}
\multicolumn{1}{c}{$\mathrm{X}$} \\
(also Province \\
of Canada \\
payments)
\end{tabular} & & $\mathbf{x}$ \\
\hline $\begin{array}{l}\text { Bonds or debentures issued by a } \\
\text { charitable, educational, or } \\
\text { philanthropic corporation secured } \\
\text { by the assignment of an adequate } \\
\text { Province of Canada subsidy }\end{array}$ & $\mathbf{X}$ & $\mathbf{X}$ & $\mathbf{x}$ & $\mathbf{x}$ & $\mathbf{X}$ & & & $\mathbf{X}$ \\
\hline
\end{tabular}




\begin{tabular}{|c|c|c|c|c|c|c|c|c|}
\hline Description & $\begin{array}{l}\text { Private } \\
\text { Sector } \\
\text { Pensions }\end{array}$ & $\begin{array}{l}\text { Public } \\
\text { Sector } \\
\text { Pensions }\end{array}$ & $\begin{array}{l}\text { Mutual } \\
\text { Funds }\end{array}$ & $\begin{array}{l}\text { Insurance } \\
\text { Co's }\end{array}$ & $\begin{array}{l}\text { Trust Corps. } \\
\text { (deposits and } \\
\text { investments) }\end{array}$ & Trustees & $\begin{array}{l}\text { Credit } \\
\text { Unions }\end{array}$ & $\begin{array}{l}\text { Heritage } \\
\text { Savings } \\
\text { Trust Fund }\end{array}$ \\
\hline $\begin{array}{l}10 \text { year seasoned bonds, } \\
\text { debentures, etc. of a corporation } \\
\text { that are fully secured by real } \\
\text { estate, plant or equipment }\end{array}$ & $\mathrm{x}$ & $\mathrm{x}$ & $\mathrm{x}$ & $\mathbf{x}$ & $\mathbf{x}$ & & & $\mathbf{x}$ \\
\hline $\begin{array}{l}\text { Bonds, debentures, etc. of a } \\
\text { Canada or a Province of Canada } \\
\text { recognized infrastructure } \\
\text { authority }\end{array}$ & $\mathbf{x}$ & $\begin{array}{l}\quad \mathrm{X} \\
\text { (also other } \\
\text { infrastructure } \\
\text { authorities) }\end{array}$ & $\mathrm{x}$ & \begin{tabular}{l}
$\quad \mathrm{X}$ \\
\multicolumn{1}{c}{$\mathrm{X}$} \\
(only authorities \\
in jurisdictions \\
where the \\
company carries \\
on business)
\end{tabular} & $\mathrm{X}$ & & & $\begin{array}{l}\quad \mathrm{X} \\
\text { (corporations } \\
\text { only) }\end{array}$ \\
\hline $\begin{array}{l}\text { Bonds, debentures and other } \\
\text { securities issued or guaranteed by } \\
\text { the World Bank, the Inter } \\
\text { American Development Bank or } \\
\text { the Asian Development Bank }\end{array}$ & $x$ & $x$ & $x$ & $\begin{array}{l}\quad \text { X } \\
\text { (only in Canada, } \\
\text { UK, Common- } \\
\text { wealth or US } \\
\text { currency) }\end{array}$ & $\mathrm{x}$ & $\begin{array}{l}\quad \text { X } \\
\text { (if Canada, } \\
\text { UK, Common- } \\
\text { wealth or US } \\
\text { currency for } \\
\text { World Bank, } \\
\text { otherwise } \\
\text { Canada or US } \\
\text { currency only) }\end{array}$ & & $\mathrm{X}$ \\
\hline $\begin{array}{l}\text { Debentures or other evidence of } \\
\text { indebtedness of a Canada or } \\
\text { Province of Canada mortgage } \\
\text { investment company }\end{array}$ & $\mathrm{X}$ & $\underset{\text { (federal only) }}{\mathrm{X}}$ & $\mathrm{X}$ & $\underset{\text { (federal only) }}{\mathrm{X}}$ & $X$ & & & $\begin{array}{l}\mathrm{X} \\
\text { (all securities of } \\
\text { federal company) }\end{array}$ \\
\hline $\begin{array}{l}\text { Bonds, debentures, etc. of a } \\
\text { corporation that are fully secured } \\
\text { by a charge to a trustee of real } \\
\text { estate, plant or equipment, or } \\
\text { authorized bond, debenture or } \\
\text { share investments }\end{array}$ & $\mathbf{x}$ & $\mathrm{x}$ & $\mathrm{x}$ & $\mathbf{x}$ & $\mathrm{x}$ & \begin{tabular}{l}
\multicolumn{1}{c}{$\mathrm{X}$} \\
(Canadian \\
corporations \\
only, provided \\
preferred or \\
common \\
shares on an \\
earnings and \\
dividend basis \\
are authorized)
\end{tabular} & & $\mathbf{x}$ \\
\hline
\end{tabular}




\begin{tabular}{|c|c|c|c|c|c|c|c|c|}
\hline Description & \begin{tabular}{|l} 
Private \\
Sector \\
Pensions
\end{tabular} & \begin{tabular}{|l} 
Public \\
Sector \\
Pensions
\end{tabular} & $\begin{array}{l}\text { Mutual } \\
\text { Funds }\end{array}$ & $\begin{array}{l}\text { Insurance } \\
\text { Co's }\end{array}$ & $\begin{array}{l}\text { Trust Corps. } \\
\text { (deposits and } \\
\text { investments) }\end{array}$ & Trustees & $\begin{array}{l}\text { Credit } \\
\text { Unions }\end{array}$ & $\begin{array}{l}\text { Heritage } \\
\text { Savings } \\
\text { Trust Fund }\end{array}$ \\
\hline $\begin{array}{l}\text { Bonds, debentures, etc. insured } \\
\text { by a federally registered insurance } \\
\text { company }\end{array}$ & $\mathrm{x}$ & $\mathbf{x}$ & $x$ & $x$ & $x$ & & & \\
\hline $\begin{array}{l}\text { Obligations issued by a trustee for } \\
\text { a corporation, to finance the } \\
\text { acquisition of transportation } \\
\text { equipment and secured by such } \\
\text { equipment }\end{array}$ & $\mathrm{X}$ & $\mathrm{x}$ & $x$ & \begin{tabular}{l}
\multicolumn{1}{c}{$\mathrm{X}$} \\
(Canada or US \\
railway \\
companies only)
\end{tabular} & $\mathrm{X}$ & & & \begin{tabular}{l}
\multicolumn{1}{c}{$\mathrm{X}$} \\
(Canada or US \\
companies only \\
and for use only \\
on railways or \\
public highways)
\end{tabular} \\
\hline $\begin{array}{l}\text { Bonds, debentures, etc. of a } \\
\text { corporation whose preferred } \\
\text { shares or common shares are } \\
\text { authorized investments }\end{array}$ & \begin{tabular}{l}
\multicolumn{1}{c}{$\mathrm{X}$} \\
(subject to 3:1 \\
debt / \\
capitalization \\
ratio)
\end{tabular} & \begin{tabular}{|l}
\multicolumn{1}{c}{$\mathrm{X}$} \\
(subject to 3:1 \\
debt / \\
capitalization \\
ratio)
\end{tabular} & $\mathrm{x}$ & $x$ & $\mathrm{X}$ & $\begin{array}{l}\quad \text { X } \\
\text { (Canada } \\
\text { companies } \\
\text { only) }\end{array}$ & & $\begin{array}{l}\quad \mathrm{X} \\
\text { (subject to } \\
\text { 3:1 debt / } \\
\text { capitalization } \\
\text { ratio) }\end{array}$ \\
\hline $\begin{array}{l}\text { Bonds, debentures, etc. of or } \\
\text { guaranteed by a corporation that } \\
\text { in the last five years has had } 10 \mathrm{x} \\
\text { earnings coverage in total and at } \\
\text { least } 1 \text { ? } \mathrm{x} \text { earnings coverage in } 4 \\
\text { of such years, or guaranteed by a } \\
\text { corporation whose common } \\
\text { shares are authorized subject to } \\
\text { 3:1 debt / capitalization ratio }\end{array}$ & $\mathrm{x}$ & $x$ & $x$ & $\begin{array}{c}\mathrm{X} \\
\text { (no debt / } \\
\text { capitalization test) }\end{array}$ & $\mathbf{x}$ & & & $x$ \\
\hline $\begin{array}{l}\text { Guaranteed minimum rate of } \\
\text { return contract issued by a } \\
\text { Canadian registered life insurer }\end{array}$ & $\mathbf{x}$ & & $\mathbf{x}$ & & $x$ & & & \\
\hline
\end{tabular}




\begin{tabular}{|c|c|c|c|c|c|c|c|c|}
\hline Description & $\begin{array}{l}\text { Private } \\
\text { Sector } \\
\text { Pensions }\end{array}$ & $\begin{array}{l}\text { Public } \\
\text { Sector } \\
\text { Pensions }\end{array}$ & $\begin{array}{l}\text { Mutual } \\
\text { Funds }\end{array}$ & $\begin{array}{l}\text { Insurance } \\
\text { Co's }\end{array}$ & $\begin{array}{l}\text { Trust Corps. } \\
\text { (deposits and } \\
\text { investments) }\end{array}$ & Trustees & $\begin{array}{l}\text { Credit } \\
\text { Unions }\end{array}$ & $\begin{array}{l}\text { Heritage } \\
\text { Savings } \\
\text { Trust Fund }\end{array}$ \\
\hline $\begin{array}{l}\text { Contract issued by Canadian } \\
\text { registered life insurer, invested in } \\
\text { authorized investments and } \\
\text { utilizing segregated funds }\end{array}$ & $\mathrm{X}$ & & $\mathbf{x}$ & & $\mathbf{X}$ & & & \\
\hline $\begin{array}{l}\text { Canadian trust company } \\
\text { guaranteed investment certificates } \\
\text { where the trust company's shares } \\
\text { are authorized investments }\end{array}$ & $\mathrm{X}$ & $\mathrm{X}$ & $\mathrm{X}$ & & $\mathrm{X}$ & \begin{tabular}{|l|}
$\quad$ X \\
(no \\
requirement for \\
shares to be \\
authorized \\
investments)
\end{tabular} & & $\mathrm{X}$ \\
\hline $\begin{array}{l}\text { Bank certificates of deposits, } \\
\text { deposit receipts or other } \\
\text { evidences of indebtedness }\end{array}$ & & $\begin{array}{l}\quad \mathrm{X} \\
\text { (includes } \\
\text { treasury } \\
\text { branches) }\end{array}$ & $\mathrm{X}$ & & $\mathrm{X}$ & $\mathrm{X}$ & $\begin{array}{l}\quad \text { X } \\
\text { (also deposits } \\
\text { with the Credit } \\
\text { Union Central } \\
\text { or any CDIC } \\
\text { insured } \\
\text { institution) }\end{array}$ & \begin{tabular}{l}
\multicolumn{1}{c}{$\mathrm{X}$} \\
(includes treasury \\
branches)
\end{tabular} \\
\hline $\begin{array}{l}\text { Securities unconditionally } \\
\text { guaranteed by a bank }\end{array}$ & & $x$ & $X$ & & $\mathrm{X}$ & & & $\begin{array}{l}\quad \mathrm{X} \\
\text { (includes treasury } \\
\text { branches) }\end{array}$ \\
\hline $\begin{array}{l}\text { Loans secured by investment } \\
\text { certificates or life insurance } \\
\text { policies }\end{array}$ & & & $\mathbf{X}$ & \begin{tabular}{l}
\multicolumn{1}{c}{ X } \\
(life insurance \\
policies of the \\
company or \\
Alberta insurers \\
only)
\end{tabular} & $\mathbf{X}$ & & & \\
\hline
\end{tabular}




\begin{tabular}{|c|c|c|c|c|c|c|c|c|}
\hline Description & $\begin{array}{l}\text { Private } \\
\text { Sector } \\
\text { Pensions }\end{array}$ & $\begin{array}{l}\text { Public } \\
\text { Sector } \\
\text { Pensions }\end{array}$ & $\begin{array}{l}\text { Mutual } \\
\text { Funds }\end{array}$ & $\begin{array}{l}\text { Insurance } \\
\text { Co's }\end{array}$ & $\begin{array}{l}\text { Trust Corps. } \\
\text { (deposits and } \\
\text { investments) }\end{array}$ & Trustees & $\begin{array}{l}\text { Credit } \\
\text { Unions }\end{array}$ & $\begin{array}{l}\text { Heritage } \\
\text { Savings } \\
\text { Trust Fund }\end{array}$ \\
\hline $\begin{array}{l}\text { Loans secured by authorized } \\
\text { investments }\end{array}$ & \begin{tabular}{l}
\multicolumn{1}{c|}{ X } \\
(subject to \\
investment \\
restrictions \\
applicable if \\
investment \\
made directly)
\end{tabular} & & $\mathbf{x}$ & $\begin{array}{l}\quad \text { X } \\
\text { (subject to } \\
\text { investment } \\
\text { restrictions } \\
\text { applicable if } \\
\text { investment } \\
\text { made directly) }\end{array}$ & $\mathbf{X}$ & & & $\begin{array}{c}\mathrm{X} \\
\text { (restricted) }\end{array}$ \\
\hline Personal and Commercial loans & & & & & \begin{tabular}{l}
\multicolumn{1}{c}{$\mathrm{X}$} \\
(Personal loans \\
may not exceed \\
prescribed \\
limits. \\
Commercial \\
loans includes \\
leasing and may \\
not exceed 5\% \\
of total assets)
\end{tabular} & & $\begin{array}{l}\quad \mathrm{X} \\
\text { (loans to } \\
\text { members } \\
\text { constitutes } \\
\text { primary } \\
\text { business) }\end{array}$ & \\
\hline $\begin{array}{l}\text { Equity Investments } \\
\text { Preferred shares of a corporation } \\
\text { that has paid the specified } \\
\text { dividend for } 5 \text { years or whose } \\
\text { common shares are authorized } \\
\text { investments }\end{array}$ & $\mathbf{X}$ & $\mathbf{X}$ & $\mathbf{X}$ & $\mathbf{x}$ & $\mathbf{X}$ & $\begin{array}{l}\quad \text { X } \\
\text { (Canadian } \\
\text { corporations } \\
\text { only, subject to } \\
\text { not more than } \\
30 \% \text { of any } \\
\text { one issuer) }\end{array}$ & & $\mathbf{X}$ \\
\hline $\begin{array}{l}\text { Common shares of a corporation } \\
\text { which during four of the last five } \\
\text { years has paid dividends or had } \\
\text { earnings available to pay } \\
\text { dividends equal to at least } 4 \% \text { of } \\
\text { the average value of the common } \\
\text { share capital stock account of the } \\
\text { corporation }\end{array}$ & $\begin{array}{l}\quad \mathrm{X} \\
\text { (subject } \\
\text { generally to a } \\
30 \% \text { holding } \\
\text { in any one } \\
\text { corporation) }\end{array}$ & $\begin{array}{l}\quad \mathrm{X} \\
\text { (subject } \\
\text { generally to a } \\
30 \% \text { holding } \\
\text { in any one } \\
\text { corporation) }\end{array}$ & $\mathbf{x}$ & $\frac{\mathrm{X}}{\text { (full } 5 \text { year test) }}$ & $\mathbf{x}$ & $\begin{array}{l}\quad \text { X } \\
\text { (Canadian } \\
\text { and US } \\
\text { corporations } \\
\text { only on basis } \\
\text { of full } 5 \text { year } \\
\text { test, and } \\
\text { subject to } 30 \% \\
\text { of any one } \\
\text { issuer) }\end{array}$ & & $\mathbf{x}$ \\
\hline
\end{tabular}




\begin{tabular}{|c|c|c|c|c|c|c|c|c|}
\hline Description & $\begin{array}{l}\text { Private } \\
\text { Sector } \\
\text { Pensions }\end{array}$ & $\begin{array}{l}\text { Public } \\
\text { Sector } \\
\text { Pensions }\end{array}$ & $\begin{array}{l}\text { Mutual } \\
\text { Funds }\end{array}$ & $\begin{array}{l}\text { Insurance } \\
\text { Co's }\end{array}$ & $\begin{array}{l}\text { Trust Corps. } \\
\text { (deposits and } \\
\text { investments) }\end{array}$ & Trustees & $\begin{array}{l}\text { Credit } \\
\text { Unions }\end{array}$ & $\begin{array}{l}\text { Heritage } \\
\text { Savings } \\
\text { Trust Fund }\end{array}$ \\
\hline $\begin{array}{l}\text { Shares of a Canadian mortgage } \\
\text { investment company }\end{array}$ & $\begin{array}{l}\quad \mathrm{X} \\
\text { (subject to not } \\
\text { more than } \\
30 \% \text { of } \\
\text { common } \\
\text { shares) }\end{array}$ & $\begin{array}{c}\mathrm{X} \\
\text { (federal only) }\end{array}$ & $\mathrm{X}$ & $\begin{array}{c}\mathrm{X} \\
\text { (federal only) }\end{array}$ & $\mathrm{x}$ & & & $\begin{array}{c}\mathrm{X} \\
\text { (federal only) }\end{array}$ \\
\hline $\begin{array}{l}\text { Securities of an Alberta Crown } \\
\text { Corporation }\end{array}$ & & $\mathbf{X}$ & $X$ & & $\mathbf{x}$ & & & $\begin{array}{l}\quad \mathrm{X} \\
\text { (also any Alberta } \\
\text { Crown agent) }\end{array}$ \\
\hline $\begin{array}{l}\text { Securities of the Alberta Energy } \\
\text { Company }\end{array}$ & & $\mathrm{x}$ & $\mathbf{x}$ & $\begin{array}{c}\mathrm{X} \\
\text { (shares only) }\end{array}$ & $x$ & $\begin{array}{c}\mathrm{X} \\
\text { (shares only) }\end{array}$ & & \\
\hline $\begin{array}{l}\text { Securities of the Export } \\
\text { Development Corporation }\end{array}$ & & $\mathbf{X}$ & $\mathbf{X}$ & & $\mathrm{X}$ & & & \\
\hline $\begin{array}{l}\text { Shares of the Credit Union } \\
\text { Central }\end{array}$ & & & $\mathbf{X}$ & & $x$ & & $x$ & \\
\hline $\begin{array}{l}\text { Securities of another person } \\
\text { acquired on the realization of } \\
\text { security }\end{array}$ & & & $\mathrm{X}$ & & $x$ & & $\mathrm{X}$ & \\
\hline $\begin{array}{l}\text { OTHER INVESTMENTS } \\
\text { Mortgages on real estate in } \\
\text { Canada up to } 75 \% \text { in value }\end{array}$ & $\mathrm{X}$ & $\mathrm{X}$ & & $\begin{array}{l}\quad \mathrm{X} \\
\text { (only Alberta or } \\
\text { where carrying } \\
\text { on business) }\end{array}$ & $\mathbf{x}$ & $\mathrm{x}$ & $\begin{array}{l}\quad \mathrm{X} \\
\text { (to members } \\
\text { subject to } \\
\text { board policy) }\end{array}$ & $\mathrm{x}$ \\
\hline $\begin{array}{l}\text { Mortgages guaranteed by Canada, } \\
\text { a Province of Canada or insured } \\
\text { by a Canada registered insurance } \\
\text { company }\end{array}$ & $\mathbf{X}$ & $\begin{array}{l}\quad \text { X } \\
\text { (also where } \\
\text { guaranteed } \\
\text { by any } \\
\text { government } \\
\text { where } \\
\text { property } \\
\text { located) }\end{array}$ & $\begin{array}{l}\quad X \\
\text { (subject to } \\
10 \% \text { of } \\
\text { total assets } \\
\text { in } \\
\text { permitted } \\
\text { mortgages) }\end{array}$ & $\begin{array}{l}\quad \mathrm{X} \\
\text { (only if insured } \\
\text { by government } \\
\text { where real estate } \\
\text { located) }\end{array}$ & $\mathbf{X}$ & & $\begin{array}{l}\quad \mathrm{X} \\
\text { (to members } \\
\text { subject to } \\
\text { board policy) }\end{array}$ & $\mathrm{x}$ \\
\hline
\end{tabular}




\begin{tabular}{|c|c|c|c|c|c|c|c|c|}
\hline Description & $\begin{array}{l}\text { Private } \\
\text { Sector } \\
\text { Pensions }\end{array}$ & $\begin{array}{l}\text { Public } \\
\text { Sector } \\
\text { Pensions }\end{array}$ & $\begin{array}{l}\text { Mutual } \\
\text { Funds }\end{array}$ & $\begin{array}{l}\text { Insurance } \\
\text { Co's }\end{array}$ & $\begin{array}{l}\text { Trust Corps. } \\
\text { (deposits and } \\
\text { investments) }\end{array}$ & Trustees & $\begin{array}{l}\text { Credit } \\
\text { Unions }\end{array}$ & $\begin{array}{l}\text { Heritage } \\
\text { Savings } \\
\text { Trust Fund }\end{array}$ \\
\hline National Housing Act Mortgages & $\mathbf{X}$ & & \begin{tabular}{l}
\multicolumn{1}{c}{$\mathrm{X}$} \\
(subject to \\
$10 \%$ of \\
total assets \\
in permitted \\
Mortgages)
\end{tabular} & $\mathbf{x}$ & $\mathbf{X}$ & $\mathbf{X}$ & \begin{tabular}{l}
\multicolumn{1}{c}{$\mathrm{X}$} \\
(to members \\
subject to \\
board policy)
\end{tabular} & \\
\hline $\begin{array}{l}\text { Income producing real estate in } \\
\text { Canada, subject to Canada or } \\
\text { authorized corporation leases } \\
\text { yielding a reasonable retum and } \\
85 \% \text { earn out within } 30 \text { years }\end{array}$ & $\begin{array}{l}\quad \mathrm{X} \\
\text { (subject to } 4 \% \\
\text { of book value } \\
\text { of assets in } \\
\text { any one } \\
\text { property) }\end{array}$ & $\begin{array}{l}\quad \mathrm{X} \\
\text { (also other } \\
\text { government } \\
\text { leases, but } \\
\text { subject to } 4 \% \\
\text { of book value } \\
\text { of assets in } \\
\text { any one } \\
\text { property) }\end{array}$ & & \begin{tabular}{l}
\multicolumn{1}{c}{$\mathrm{X}$} \\
(only Alberta or \\
where company \\
carrying on \\
business, subject \\
to .5\% of book \\
value of assets in \\
one property and \\
$5 \%$ of book value \\
of assets in total)
\end{tabular} & \begin{tabular}{l}
\multicolumn{1}{c}{ X } \\
(subject to \\
prescribed \\
limits)
\end{tabular} & & & \\
\hline $\begin{array}{l}\text { Income producing real estate in } \\
\text { Canada, subject to } 3 \text { year earnings } \\
\text { record yielding a reasonable rate } \\
\text { of return and an } 85 \% \text { eam out } \\
\text { within } 40 \text { years }\end{array}$ & $\begin{array}{l}\quad \mathrm{X} \\
\text { (subject to } 4 \% \\
\text { of book value } \\
\text { of assets in } \\
\text { any one } \\
\text { property) }\end{array}$ & $\begin{array}{l}\quad \mathrm{X} \\
\text { (including } \\
\text { resource } \\
\text { properties but } \\
\text { subject to } 4 \% \\
\text { of book value } \\
\text { of assets in } \\
\text { any one } \\
\text { property) }\end{array}$ & & & \begin{tabular}{l}
\multicolumn{1}{c}{ X } \\
(subject to \\
prescribed \\
limits)
\end{tabular} & & & \\
\hline $\begin{array}{l}\text { Canadian Resource properties } \\
\text { (as defined in Income Tax Act), } \\
\text { subject to } 3 \text { year eamings } \\
\text { recorded yielding a reasonable } \\
\text { retum and a } 75 \% \text { eam out over } \\
15 \text { years }\end{array}$ & $\begin{array}{l}\quad \mathrm{X} \\
\text { (subject to } 4 \% \\
\text { of book value } \\
\text { of assets in } \\
\text { any one } \\
\text { property) }\end{array}$ & & & & $\mathbf{x}$ & & & \\
\hline
\end{tabular}




\begin{tabular}{|c|c|c|c|c|c|c|c|c|}
\hline Description & $\begin{array}{l}\text { Private } \\
\text { Sector } \\
\text { Pensions }\end{array}$ & $\begin{array}{l}\text { Public } \\
\text { Sector } \\
\text { Pensions }\end{array}$ & $\begin{array}{l}\text { Mutual } \\
\text { Funds }\end{array}$ & $\begin{array}{l}\text { Insurance } \\
\text { Co's }\end{array}$ & $\begin{array}{l}\text { Trust Corps. } \\
\text { (deposits and } \\
\text { investments) }\end{array}$ & Trustees & $\begin{array}{l}\text { Credit } \\
\text { Unions }\end{array}$ & $\begin{array}{l}\text { Heritage } \\
\text { Savings } \\
\text { Trust Fund }\end{array}$ \\
\hline Real estate corporations & $\begin{array}{l}\quad \mathrm{X} \\
\text { (subject to } 4 \% \\
\text { in any one } \\
\text { property and } \\
10 \% \text { of book } \\
\text { value of } \\
\text { assets) }\end{array}$ & & $\mathbf{x}$ & & $\mathbf{x}$ & & & \\
\hline Canadian resource corporations & \begin{tabular}{l}
\multicolumn{1}{c}{$\mathrm{X}$} \\
subject to $2 \%$ \\
to $4 \%$ in any \\
one property \\
and $10 \%$ of \\
book value of \\
assets)
\end{tabular} & & $\mathbf{X}$ & & $\mathbf{x}$ & & & \\
\hline $\begin{array}{l}7 \% \text { Canadian real estate or } \\
\text { Canadian resource property } \\
\text { basket clause }\end{array}$ & $\begin{array}{l}\quad \mathrm{X} \\
\text { (subject to 2\% } \\
\text { in non-income } \\
\text { producing } \\
\text { properties and } \\
2 \% \text { in any one } \\
\text { real estate or } \\
\text { resource } \\
\text { property) }\end{array}$ & & & & & & & \\
\hline $\begin{array}{l}7 \% \text { basket clause other than real } \\
\text { estate or Canadian resource } \\
\text { property }\end{array}$ & $\mathbf{X}$ & $\begin{array}{l}\quad \mathrm{X} \\
\text { (7\% of book } \\
\text { value general } \\
\text { basket clause) }\end{array}$ & & $\begin{array}{l}\quad \mathrm{X} \\
\text { (no restrictions } \\
\text { other than .5\% of } \\
\text { book value of any } \\
\text { one parcel of real } \\
\text { estate) }\end{array}$ & & & $\begin{array}{l}\mathrm{X} \\
\text { (2\% general } \\
\text { basket clause) }\end{array}$ & \\
\hline
\end{tabular}




\begin{tabular}{|c|c|c|c|c|c|c|c|c|}
\hline Description & $\begin{array}{l}\text { Private } \\
\text { Sector } \\
\text { Pensions }\end{array}$ & $\begin{array}{l}\text { Public } \\
\text { Sector } \\
\text { Pensions }\end{array}$ & $\begin{array}{l}\text { Mutual } \\
\text { Funds }\end{array}$ & $\begin{array}{l}\text { Insurance } \\
\text { Co's }\end{array}$ & $\begin{array}{l}\text { Trust Corps. } \\
\text { (deposits and } \\
\text { investments) }\end{array}$ & Trustees & $\begin{array}{l}\text { Credit } \\
\text { Unions }\end{array}$ & $\begin{array}{l}\text { Heritage } \\
\text { Savings } \\
\text { Trust Fund }\end{array}$ \\
\hline Mutual Funds & $\begin{array}{l}\quad \text { X } \\
\text { (if invested in } \\
\text { authorized } \\
\text { investments } \\
\text { provided that } \\
\text { real estate } \\
\text { investment } \\
\text { trusts may not } \\
\text { have more } \\
\text { than } 10 \% \text { in } \\
\text { any property } \\
\text { and may not } \\
\text { otherwise } \\
\text { exceed } 10 \% \text { of } \\
\text { book value of } \\
\text { assets) }\end{array}$ & \begin{tabular}{l}
\multicolumn{1}{c}{$\mathrm{X}$} \\
(if invested in \\
authorized \\
investments)
\end{tabular} & \begin{tabular}{l}
\multicolumn{1}{c}{ X } \\
(subject to \\
conflicts, \\
compliance \\
with \\
securities \\
laws and \\
avoidance \\
of \\
duplication \\
of fees)
\end{tabular} & & $\mathbf{X}$ & & & \begin{tabular}{l}
\multicolumn{1}{c}{$\mathrm{X}$} \\
(if invested in \\
authorizzed \\
investments)
\end{tabular} \\
\hline Options or futures & \begin{tabular}{l}
\multicolumn{1}{c}{$X$} \\
(if part of a \\
defensive \\
strategy)
\end{tabular} & $\underset{\text { also swaps }}{\mathbf{X}}$ & $\begin{array}{l}\quad \text { X } \\
\text { (restricted } \\
\text { to clearing } \\
\text { corporation } \\
\text { call options, } \\
\text { and subject } \\
\text { to not more } \\
\text { than } 10 \% \\
\text { of net } \\
\text { assets) }\end{array}$ & & $\mathbf{x}$ & & & \\
\hline
\end{tabular}




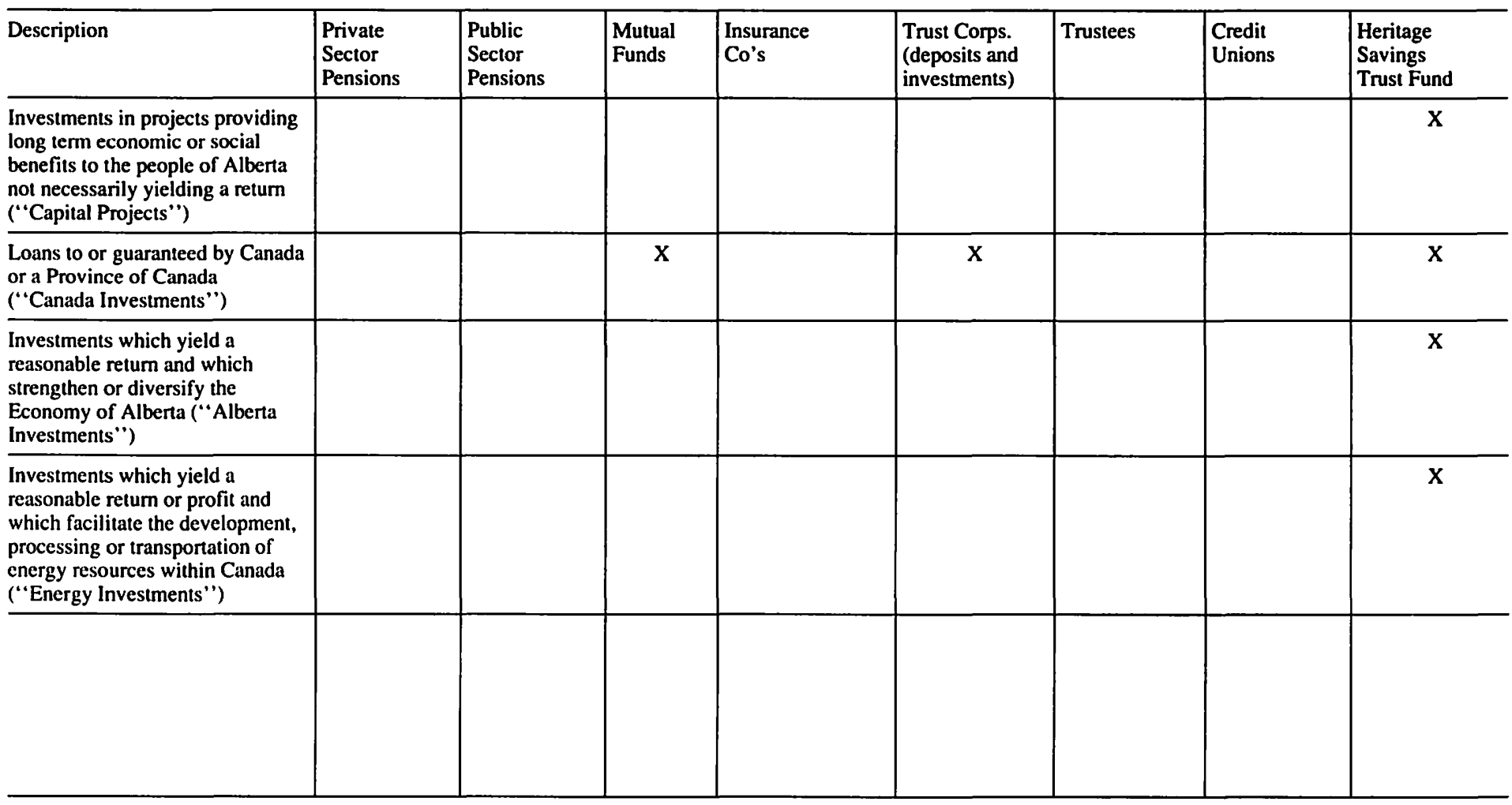




\begin{tabular}{|c|c|c|c|c|c|c|c|c|}
\hline Description & $\begin{array}{l}\text { Private } \\
\text { Sector } \\
\text { Pensions }\end{array}$ & $\begin{array}{l}\text { Public } \\
\text { Sector } \\
\text { Pensions }\end{array}$ & Mutual Funds & $\begin{array}{l}\text { Insurance } \\
\text { Co's }\end{array}$ & $\begin{array}{l}\text { Trust Corps. } \\
\text { (deposits and } \\
\text { investments) }\end{array}$ & Trustees & Credit Unions & $\begin{array}{l}\text { Heritage } \\
\text { Savings Trust } \\
\text { Fund }\end{array}$ \\
\hline $\begin{array}{l}\text { GENERAL RESTRICTION } \\
\text { ON INVESTMENTS } \\
\text { Diversification Requirements }\end{array}$ & $\begin{array}{l}\quad \text { X } \\
\text { (may not hold } \\
\text { more than } \\
10 \% \text { of book } \\
\text { value of assets } \\
\text { in the } \\
\text { securities of } \\
\text { any one issuer. } \\
\text { Direct } \\
\text { holdings of } \\
\text { real estate \& } \\
\text { Canadian } \\
\text { resource } \\
\text { properties } \\
\text { subject to } 4 \% \\
\text { of book value } \\
\text { of assets } \\
\text { ceiling. Direct } \\
\text { and in-direct } \\
\text { holdings of } \\
\text { Canadian } \\
\text { resource } \\
\text { properties } \\
\text { limited to } 15 \% \\
\text { of book value } \\
\text { of assets) }\end{array}$ & & $\begin{array}{l}\quad \text { X } \\
\text { (except for } \\
\text { Canada, } \\
\text { Province of } \\
\text { Canada or US } \\
\text { securities, } \\
\text { may not hold } \\
\text { more than } \\
10 \% \text { of net } \\
\text { assets in the } \\
\text { securities of } \\
\text { any one } \\
\text { issuer, hold } \\
\text { more than } \\
10 \% \text { of any } \\
\text { class or series } \\
\text { of class of the } \\
\text { securities of } \\
\text { any issuer nor } \\
\text { hold more } \\
\text { than } 10 \% \text { of } \\
\text { the total } \\
\text { assets of the } \\
\text { fund in } \\
\text { permitted } \\
\text { mortgages, } \\
\text { restricted } \\
\text { securities } \\
\text { warrants or } \\
\text { rights, gold or } \\
\text { gold certs, or } \\
\text { illiquid } \\
\text { investments) }\end{array}$ & \begin{tabular}{l}
\multicolumn{1}{c|}{ X } \\
(except for \\
Government of \\
Canada securities, \\
not more than \\
$10 \%$ of its funds \\
may be held in the \\
securities of any \\
one issuer, nor \\
may more than \\
$10 \%$ of any issue \\
of one corporation \\
be acquired. Not \\
more than $25 \%$ of \\
book value of \\
assets in Common \\
Shares. Not more \\
than $5 \%$ of assets \\
in income \\
producing real \\
estate or \\
leaseholds.)
\end{tabular} & \begin{tabular}{l}
\multicolumn{1}{c|}{ X } \\
(generally may \\
not hold more \\
than $10 \%$ of the \\
voting shares of \\
a corporation. \\
Loans or \\
investments in \\
respect of any \\
one person or \\
connected \\
persons may not \\
exceed \\
prescribed limit. \\
Real estate \\
investments also \\
may not exceed \\
prescribed \\
limit.)
\end{tabular} & \begin{tabular}{l}
\multicolumn{1}{c|}{$\mathrm{X}$} \\
(may not hold \\
more than $15 \%$ \\
of current \\
market value \\
of trust in \\
common shares \\
nor more than \\
$35 \%$ of current \\
market value \\
of trust in \\
preferred \\
shares and \\
secured \\
corporate debt)
\end{tabular} & $\begin{array}{l}\quad \mathrm{X} \\
\text { (may not } \\
\text { acquire more } \\
\text { than } 10 \% \text { of } \\
\text { the voting } \\
\text { shares of any } \\
\text { corporation or } \\
\text { hold in the } \\
\text { aggregate } \\
\text { voting shares } \\
\text { having an } \\
\text { aggregate } \\
\text { value in } \\
\text { excess of } 20 \% \\
\text { of its equity) }\end{array}$ & $\begin{array}{l}\quad \mathrm{X} \\
\text { (may not hold } \\
\text { more than } 25 \% \\
\text { of the fund } \\
\text { assets in Capital } \\
\text { Projects nor } \\
\text { more than } 20 \% \\
\text { of the fund } \\
\text { assets in } \\
\text { Canadian } \\
\text { Investments) }\end{array}$ \\
\hline
\end{tabular}




\begin{tabular}{|c|c|c|c|c|c|c|c|c|}
\hline Description & $\begin{array}{l}\text { Private } \\
\text { Sector } \\
\text { Pensions }\end{array}$ & $\begin{array}{l}\text { Public } \\
\text { Sector } \\
\text { Pensions }\end{array}$ & $\begin{array}{l}\text { Mutual } \\
\text { Funds }\end{array}$ & $\begin{array}{l}\text { Insurance } \\
\text { Co's }\end{array}$ & $\begin{array}{l}\text { Trust Corps. } \\
\text { (deposits and } \\
\text { investments) }\end{array}$ & Trustees & $\begin{array}{l}\text { Credit } \\
\text { Unions }\end{array}$ & $\begin{array}{l}\text { Heritage } \\
\text { Savings } \\
\text { Trust Fund }\end{array}$ \\
\hline $\begin{array}{l}\text { Related party transactions } \\
\text { restricted }\end{array}$ & $\mathbf{X}$ & & $\mathbf{X}$ & $\mathrm{x}$ & $x$ & $\mathrm{X}$ & $\mathrm{x}$ & \\
\hline $\begin{array}{l}\text { May not purchase securities for } \\
\text { the purpose of exercising control } \\
\text { or management of an issuer }\end{array}$ & & & $X$ & & & & & \\
\hline $\begin{array}{l}\text { May not purchase or sell } \\
\text { commodities or commodity } \\
\text { futures, contracts or commodity } \\
\text { options other than cash or gold or } \\
\text { unless otherwise permitted }\end{array}$ & & & $x$ & & & & & \\
\hline $\begin{array}{l}\text { Restrictions on borrowing and the } \\
\text { acquisition of securities which } \\
\text { require additional contributions }\end{array}$ & & & $\mathbf{x}$ & & $\begin{array}{l}\quad \mathrm{X} \\
\text { (restriction on } \\
\text { borrowing) }\end{array}$ & & $\begin{array}{l}\quad \mathrm{X} \\
\text { (restrictions } \\
\text { on borrowing) }\end{array}$ & \\
\hline $\begin{array}{l}\text { May not purchase securities on } \\
\text { margin or sell securities short and } \\
\text { may not lend portfolio securities }\end{array}$ & & & $\mathbf{X}$ & & & & & \\
\hline $\begin{array}{l}\text { May not guarantee the securities } \\
\text { or obligations of any other person } \\
\text { or corporation }\end{array}$ & & & $\mathrm{X}$ & & & & & \\
\hline $\begin{array}{l}\text { Generally may only purchase } \\
\text { securities through normal market } \\
\text { facilities }\end{array}$ & & & $\mathrm{X}$ & & & & & \\
\hline $\begin{array}{l}\text { All investments and loans must be } \\
\text { reasonable and proper }\end{array}$ & & & & & & $x$ & & \\
\hline
\end{tabular}




\begin{tabular}{|c|c|c|c|c|c|c|c|c|}
\hline Description & \begin{tabular}{|l} 
Private \\
Sector \\
Pensions
\end{tabular} & \begin{tabular}{|l} 
Public \\
Sector \\
Pensions
\end{tabular} & $\begin{array}{l}\text { Mutual } \\
\text { Funds }\end{array}$ & $\begin{array}{l}\text { Insurance } \\
\text { Co's }\end{array}$ & $\begin{array}{l}\text { Trust Corps. } \\
\text { (deposits and } \\
\text { investments) }\end{array}$ & Trustees & $\begin{array}{l}\text { Credit } \\
\text { Unions }\end{array}$ & $\begin{array}{l}\text { Heritage } \\
\text { Savings } \\
\text { Trust Fund }\end{array}$ \\
\hline $\begin{array}{l}\text { Must adhere to prudent } \\
\text { investment standards which in the } \\
\text { overall context of an investment } \\
\text { portfolio, a reasonably prudent } \\
\text { person would apply to } \\
\text { investments made on behalf of } \\
\text { another person with whom there } \\
\text { exists a fiduciary relationship to } \\
\text { make such investments, without } \\
\text { undue risk of loss or impairment } \\
\text { and with a reasonable expectation } \\
\text { of fair retum or appreciation }\end{array}$ & & & & & $\begin{array}{c}\mathrm{X} \\
\text { (Applies to all } \\
\text { investments) }\end{array}$ & & \begin{tabular}{|l}
\multicolumn{1}{c}{$\mathrm{X}$} \\
(May only \\
invest in \\
authorized \\
investments if \\
test met)
\end{tabular} & \\
\hline $\begin{array}{l}\text { Except pursuant to the realisation } \\
\text { of security, may not acquire any } \\
\text { land unless needed to carry on } \\
\text { business or acquire any securities } \\
\text { not specifically authorized }\end{array}$ & & & & & & & $x$ & \\
\hline
\end{tabular}

